\title{
Effect of ceramic membrane channel geometry and uniform transmembrane pressure on limiting flux and serum protein removal during skim milk microfiltration ${ }^{1}$
}

\author{
Michael C. Adams, Emily E. Hurt, and David M. Barbano ${ }^{2}$ \\ Northeast Dairy Foods Research Center, Department of Food Science, Cornell University, Ithaca, NY 14853
}

\begin{abstract}
Our objectives were to determine the effects of a ceramic microfiltration (MF) membrane's retentate flow channel geometry (round or diamond-shaped) and uniform transmembrane pressure (UTP) on limiting flux (LF) and serum protein (SP) removal during skim milk $\mathrm{MF}$ at a temperature of $50^{\circ} \mathrm{C}$, a retentate protein concentration of $8.5 \%$, and an average cross-flow velocity of $7 \mathrm{~m} \cdot \mathrm{s}^{-1}$. Performance of membranes with round and diamond flow channels was compared in UTP mode. Performance of the membrane with round flow channels was compared with and without UTP. Using UTP with round flow channel MF membranes increased the LF by $5 \%$ when compared with not using UTP, but SP removal was not affected by the use of UTP. Using membranes with round channels instead of diamondshaped channels in UTP mode increased the LF by $24 \%$. This increase was associated with a $25 \%$ increase in Reynolds number and can be explained by lower shear at the vertices of the diamond-shaped channel's surface. The SP removal factor of the diamond channel system was higher than the SP removal factor of the round channel system below the LF. However, the diamond channel system passed more casein into the MF permeate than the round channel system. Because only one batch of each membrane was tested in our study, it was not possible to determine if the differences in protein rejection between channel geometries were due to the membrane design or random manufacturing variation. Despite the lower LF of the diamond channel system, the $47 \%$ increase in membrane module surface area of the diamond channel system produced a modular permeate removal rate that was at least 19\% higher than the round channel system. Consequently, using
\end{abstract}

Received April 27, 2015.

Accepted June 25, 2015

${ }^{1}$ Use of names, names of ingredients, and identification of specific models of equipment is for scientific clarity and does not constitute any endorsement of product by authors, Cornell University or the Northeast Dairy Foods Research Center.

${ }^{2}$ Corresponding author: dmb37@cornell.edu diamond channel membranes instead of round channel membranes could reduce some of the costs associated with ceramic MF of skim milk if fewer membrane modules could be used to attain the required membrane area.

Key words: microfiltration, limiting flux, serum protein, ceramic membranes

\section{INTRODUCTION}

Microfiltration (MF) is a pressure-driven membrane process that can be used to separate milk serum proteins (SP) from casein micelles in skim milk. The membranes used in MF can be manufactured in a variety of different geometries from numerous materials (Zulewska et al., 2009). Ceramic MF membranes foul less easily and can remove a higher percentage of skim milk SP than polymeric membranes (Zulewska et al., 2009). Consequently, using ceramic membranes for SP removal reduces the amount of diafiltration necessary to meet a certain SP removal target (Hurt and Barbano, 2010) and reduces the water required to produce high-purity micellar casein concentrates and SP concentrates. However, a barrier to the use of ceramic MF membranes has been their high costs relative to polymeric membranes (Cheryan, 1998). Part of the cost difference may be reduced in the long run by the longer lifetimes, more effective cleaning and sanitation, and higher permeate fluxes of ceramic membranes. When microfiltering skim milk at a $3 \times$ concentration factor $(\mathbf{C F})$, the flux of a ceramic membrane is about $5 \times$ that of a polymeric membrane (75 vs. $15 \mathrm{~kg} \cdot \mathrm{m}^{-2} \cdot \mathrm{h}^{-1}$; Zulewska et al., 2009). The higher flux of a ceramic system can be attributed to the increase in shear rate and shear stress near the surface of the membrane (Gesan-Guiziou et al., 1999) caused by higher cross-flow velocities in the retentate recirculation loop. Increased shear will increase backdiffusion of casein micelles from the surface of the membrane, thereby reducing fouling and promoting SP passage (Belfort et al., 1994; Gesan-Guiziou et al., 1999). Flux in a given ceramic system is a function of the skim milk-soluble calcium concentration (Adams 
et al., 2015), the retentate viscosity, and the average cross-flow velocity in the retentate recirculation loop (Hurt et al., 2015a). The maximum flux achievable by increasing transmembrane pressure (TMP) is known as the limiting flux (LF) (Bacchin et al., 2006). Optimization of skim processing conditions resulting in increased LF will increase throughput and reduce the costs of the MF process. Adams et al. (2015) demonstrated this by removing soluble calcium from the skim milk MF feed, thereby increasing the LF by $41 \%$.

One way to reduce the costs of ceramic membranes from a design perspective would be to increase the membrane surface area per unit volume of a module. Ceramic membranes are housed in stainless steel modules. Cross-flow filtration ceramic modules account for between 10 and $50 \%$ of a ceramic MF system costs. Large systems $\left(>1,000 \mathrm{~m}^{2}\right)$ are on the high end of this range and small systems $\left(<50 \mathrm{~m}^{2}\right)$ are on the low end (Jacques Guibaud, Pall Corp. Food \& Beverage, Bazet, France, personal communication). Between 1 and 4 of these membrane housings can be placed in a single recirculation loop. By increasing membrane surface area per unit volume of a module, fewer modules and recirculation pumps could potentially be used in a system of a given processing capacity, thereby reducing fixed and some variable costs. Round retentate flow channels are typically used in tubular ceramic membranes, but the round shape is not the most compact geometry available. Diamond-shaped retentate flow channels are available that provide $47 \%$ more surface area than round retentate flow channels of the same equivalent diameter. Adams and Barbano (2013) evaluated Isoflux (TAMI Industries, Nyons, France) ceramic membranes with noncircular channels and determined that they removed less SP than other ceramic membranes with round flow channels. However, the effect of channel geometry on SP removal could not be established by Adams and Barbano (2013) because the Isoflux membranes also had a different selective layer structure than the round flow channel membranes they were compared with, which may have increased SP rejection independent of the difference in flow channel geometry. No other studies have been reported that have determined the effect of noncircular channel geometries on tubular ceramic membrane LF with dairy fluids. Chiu et al. (2005) microfiltered wastewater using MF membranes with star-shaped retentate flow channels and suggested that the high critical flux observed, relative to other studies which used round channels, may have resulted from flow instabilities caused by the noncircular design of the star-shaped channels. However, the Chiu et al. (2005) experimental design did not include a round channel control and, unlike the other studies which were used for comparison, the feed used in the star- shaped channel study was clarified before filtration. These discrepancies make it difficult to compare data between the round and star-shaped membrane channels among studies. Therefore, more data are required to make accurate conclusions on the effect of channel geometry on LF.

Uniform transmembrane pressure (UTP) involves recirculating permeate co-currently with the retentate to match the pressure drop on the retentate side of the membrane $(\boldsymbol{\Delta} \mathbf{P})$ and produce even permeation along the length of the membrane (Sandblom, 1978). Even permeation is purported to reduce fouling at the inlet of the membrane and has been used successfully to remove SP and bacteria from skim milk (Elwell and Barbano, 2006; Hurt et al., 2010). Pafylias et al. (1996) compared ceramic MF systems with and without UTP and observed over a $100 \%$ increase in flux (875 vs. 410 $\mathrm{L} \cdot \mathrm{m}^{-2} \cdot \mathrm{h}^{-1}$ ) at $50^{\circ} \mathrm{C}$ when UTP was used to microfilter $1 \%$ fat milk with 1.4- $\mu$ m Membralox membranes. Under the same conditions, skim milk flux was initially higher with UTP, but rapidly fell to the same flux (400 $\mathrm{L} \cdot \mathrm{m}^{-2} \cdot \mathrm{h}^{-1}$ ) as the operation without UTP (Pafylias et al., 1996). Pafylias et al. (1996) concluded that foaming in skim milk might have led to fouling by air bubbles at membrane surface, though this was not verified. Vadi and Rizvi (2001) found no improvement in flux as a result of using UTP with $0.2-\mu \mathrm{m}$ ceramic membranes to MF skim milk below a $4 \times \mathrm{CF}$ at $50^{\circ} \mathrm{C}$. However, they did not assess the effect of UTP on SP removal. Another way to reduce the costs associated with some ceramic MF systems would be to eliminate the fixed and variable costs associated with the permeate recirculation pump in UTP systems. However, it is unknown if this would reduce SP passage in a skim milk MF process.

Our objectives were to determine the effects of ceramic membrane channel geometry and UTP on LF and SP removal during MF of skim milk at a temperature of $50^{\circ} \mathrm{C}$, a retentate protein concentration of $8.5 \%$, and an average cross-flow velocity of $7 \mathrm{~m} \cdot \mathrm{s}^{-1}$. Principles of fluid dynamics were used to explain our results.

\section{MATERIALS AND METHODS}

\section{Experimental Design}

A completely randomized split block design was employed in which the membrane type or use of UTP was the whole-plot factor, flux was the sub-plot factor, and replicate was the blocking factor. The experiment was replicated 3 times in different weeks with 3 different batches of pasteurized skim milk. Each replicate took place over $4 \mathrm{~d}$ within a week. On the first day, raw skim milk $(1,100 \mathrm{~kg})$ was procured from the Cornell University Dairy Plant and pasteurized using a plate 


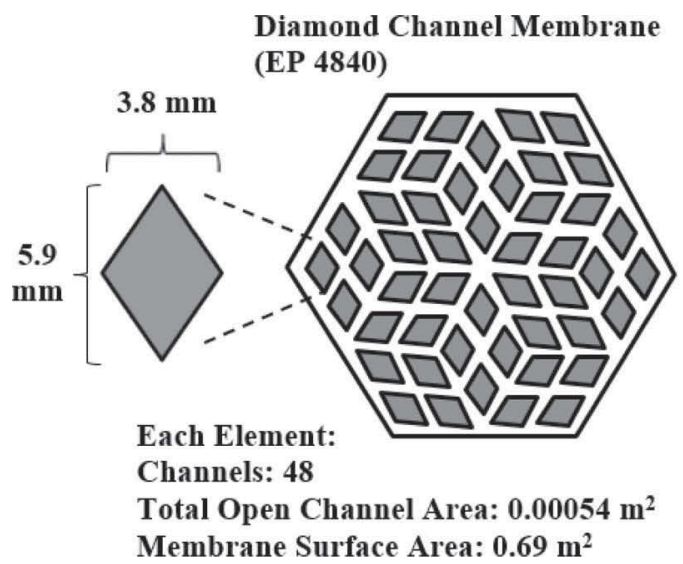

Round Channel Membrane

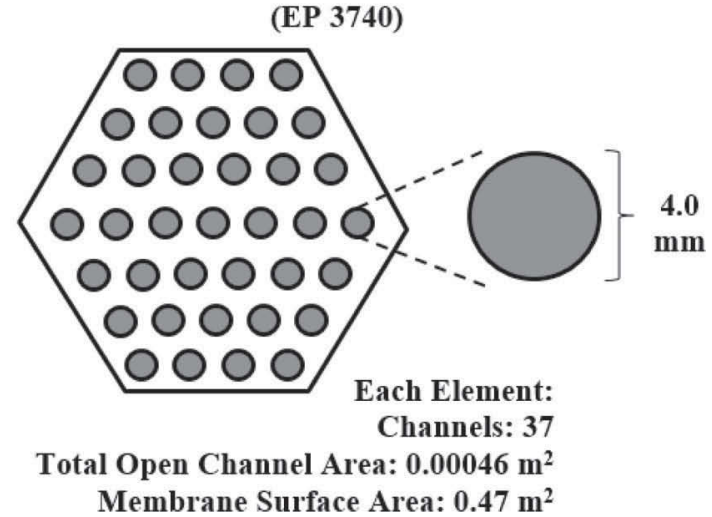

Figure 1. Cross sectional views of 4-mm equivalent diameter diamond channel and 4-mm diameter round channel membrane elements with relevant measurements.

heat exchanger equipped with 3 sections: regeneration, heating, and cooling (model 080-S, AGC Engineering, Manassas, VA). Pasteurization temperature and holding time were $72^{\circ} \mathrm{C}$ for $16 \mathrm{~s}$ to minimize heat denaturation of SP. The milk was cooled to $4^{\circ} \mathrm{C}$ and stored at $\leq 6^{\circ} \mathrm{C}$ in a $1,136-\mathrm{L}$ tote (Metano IBC Services, Inc., Perrineville, NJ) until MF processing. The second, third, and fourth days were used to MF skim milk using the following 3 combinations of membrane conditions: round flow channel membranes without UTP, round flow channel membranes with UTP, and diamond flow channel membranes with UTP.

\section{MF Operation}

On the evening before processing, the pilot-scale MF system (Tetra Alcross M7, TetraPak Filtration Systems, Aarhus, Denmark) was cleaned as described by Hurt et al., (2010). Briefly, the nitric acid storage solution $(0.55 \% \mathrm{vol} / \mathrm{vol})$ was flushed out of the system using $25^{\circ} \mathrm{C}$ reverse osmosis (RO) water until the flush water was neutral (15 min). The MF system was gradually heated $\left(<10^{\circ} \mathrm{C} / \mathrm{min}\right)$ to $80^{\circ} \mathrm{C}$ using $85^{\circ} \mathrm{C} \mathrm{RO}$ water, Ultrasil 25 (Ecolab Inc., St. Paul, MN) was added to the system $(1.95 \% \mathrm{vol} / \mathrm{vol})$, and the Ultrasil caustic solution was recirculated for 30 min with the feed and retentate recirculation pumps on. After cleaning, the system was gradually cooled $\left(<10^{\circ} \mathrm{C} / \mathrm{min}\right)$ to $50^{\circ} \mathrm{C}$ and the caustic solution was flushed out of the system using $25^{\circ} \mathrm{C}$ RO water until the flush water was neutral (15 $\min )$.

The system was equipped with either Membralox ceramic membranes with round flow channels (part number EP3740, Pall Corp., East Hills, NY) or Membralox ceramic membranes with diamond-shaped flow channels (part number EP4840, Pall Corp.). Both membranes were made of zirconia and composed of a selective layer (100 nm nominal pore size), an intermediate layer (0.8 $\mu \mathrm{m}$ nominal pore size), and a support structure (12 $\mu \mathrm{m}$ nominal pore size). For each membrane type, the system's stainless steel membrane module housed 3 membrane elements. The round channel membranes contained 37 retentate flow channels per element that were $4 \mathrm{~mm}$ in diameter and $1.02 \mathrm{~m}$ in length for a total module membrane surface area of $1.41 \mathrm{~m}^{2}$. The diamond channel membranes contained 48 retentate flow channels per element that were $4 \mathrm{~mm}$ in equivalent diameter and $1.02 \mathrm{~m}$ in length for a total module membrane surface area of $2.07 \mathrm{~m}^{2}$. Relevant measurements for both membranes are shown in Figure 1.

The MF system was identical to the one described by Hurt et al. (2010), with the following exceptions: the membrane modules described above were used, a digital magnetic mass flow meter (model AM204DH, Yokogawa Electronic Corp., Tokyo, Japan) was used to measure the retentate removal rate, polypropylene beads (Borealis granulates, Pall Corp.) were used to fill the permeate side of the membrane module, and screened gaskets (40MPUS15, Twinco Inc., West Falls, NY) were used to retain the beads within the module. The retentate flow meter was added to improve control of the retentate flow rate and, consequently, the $\mathrm{CF}$. The additions of the beads and gaskets were made so that an adequate pressure drop on the permeate side of the membrane could be achieved so that the MF system could be operated in UTP mode.

Pressure gauges were mounted on the system to monitor retentate pressure at the membrane inlet $\left(\mathbf{P}_{\mathbf{R i}}\right)$, retentate pressure at the membrane outlet $\left(\mathbf{P}_{\mathbf{R o}}\right)$, permeate pressure at the membrane inlet $\left(\mathbf{P}_{\mathbf{P i}_{\mathbf{i}}}\right)$, and permeate pressure at the membrane outlet $\left(\mathbf{P}_{\mathbf{P o}_{\mathbf{0}}}\right)$. On the morning of processing, the MF system was flushed 
with $50^{\circ} \mathrm{C} \mathrm{RO}$ water to heat the system and remove the storage acid. A clean membrane water flux was measured using $50^{\circ} \mathrm{C} \mathrm{RO}$ water and pressure gauges were corrected to account for their vertical heights so that accurate TMP at the inlet and outlet and average TMP ( $_{\mathbf{T M P}}, \mathbf{T} \mathbf{T} \mathbf{P}_{\mathbf{o}}$, and $\mathbf{T M P} \mathbf{P}_{\mathrm{avg}}$, respectively) could be calculated (Hurt et al., 2010). Initial MF processing conditions were then set on RO water. To do this, the retentate recirculation pump was turned on and controlled using a variable frequency drive (MC Series, model M12100C, Lenze AC Tech, Uxbridge, MA) to achieve an average cross-flow velocity of $7 \mathrm{~m} \cdot \mathrm{s}^{-1}$. The permeate valve was then opened to achieve a flux of $45 \mathrm{~kg} \cdot \mathrm{m}^{-2} \cdot \mathrm{h}^{-1}$ and the retentate valve was opened to achieve a $\mathrm{CF}$ of 2.98 times.

The round and diamond-shaped channel membranes were each operated in UTP mode. The only difference between operation with and without UTP was the use of a permeate recirculation pump. In UTP mode, the permeate recirculation pump was turned on when the retentate recirculation pump was turned on. A diaphragm valve in the permeate recirculation loop was opened or closed to maintain the difference between $\mathrm{TMP}_{\mathrm{i}}$ and $\mathrm{TMP}_{\mathrm{o}}(\boldsymbol{\Delta} \mathbf{T M P})$ at $25 \pm 3 \mathrm{kPa}$. The round channel membranes were also operated without UTP. When UTP was not used, the permeate pump remained off, the permeate recirculation loop was removed from the system, and a pressure gauge was placed on the permeate outlet port. The beads used to fill the dead volume of the module remained in the module when UTP was not used. The presence of these beads did not affect pressure gauge measurements when the permeate recirculation pump was not in use.

Once processing conditions were set with water running in the system, the skim milk was heated to $50^{\circ} \mathrm{C}$ by pumping through a plate heat exchanger (model 080$\mathrm{S}, \mathrm{AGC}$ Engineering) at $60^{\circ} \mathrm{C}$. A prefilter was placed in-line and downstream of the heat exchanger that was used to warm the skim milk as a precautionary measure to remove any possible particles in the milk that could damage the selective layer surface within the ceramic membranes. The prefilter consisted of a filter housing (Nexis, $30 \mathrm{~cm}$ length, Pall Corp.) and a 10- $\mu \mathrm{m}$ polypropylene filter (Nexis T 10-30U-M7S, Pall Corp.). Skim milk was pumped directly from the prefilter into a 379-L jacketed vat and the prefilter was discarded after each use. The skim milk was held in the vat at $50^{\circ} \mathrm{C}$ for 15 min before the MF feed source was switched from $50^{\circ} \mathrm{C} \mathrm{RO}$ water to $50^{\circ} \mathrm{C}$ skim milk $(360 \mathrm{~kg})$ and the $\mathrm{RO}$ water was flushed out of the system. Permeate and retentate were collected into standard stainless steel 38-L milk cans, weighed, and then discarded while flushing. In total, $195 \mathrm{~kg}$ of permeate, retentate, and RO water was collected to bring the protein concentration in the retentate recirculation loop to the target $8.5 \%$, as determined by mid-infrared spectroscopy (MIR). Once the water had been flushed from the system (time elapsed $=2 \mathrm{~h}$ ), the retentate and permeate were recycled back to the feed vat and the remainder of the experiment was conducted in total recycle (elapsed time $=5 \mathrm{~h}$ ). While the system was in recycle mode, a flux-stepping method similar to the ones described by Samuelsson et al. (1997) and Bacchin et al. (2006) was employed to determine the LF. After the system was in total recycle, it was operated at a flux of $45 \mathrm{~kg} \cdot \mathrm{m}^{-2} \cdot \mathrm{h}^{-1}$ for 1 h. Flux was then increased by 10 to $20 \mathrm{~kg} \cdot \mathrm{m}^{-2} \cdot \mathrm{h}^{-1}$ each hour until a LF was reached.

During the flux-stepping procedure, permeate mass flux and CF were measured every 15 min by collecting retentate and permeate from the system into 2 tared 19-L buckets. After 2 min of collection, the buckets were weighed to the nearest $\mathrm{g}$ using a balance (model MS32000L, Mettler Toledo, Bedford, MA) and the CF was calculated. Samples of permeate and retentate were collected and analyzed by MIR to monitor the composition every $15 \mathrm{~min}$. After $45 \mathrm{~min}$ at each flux, the retentate and permeate were collected continuously for 15 min into separate milk cans and samples for analytical testing were collected from each can. The permeate and retentate that remained after sampling were added back to the feed vat and the flux was increased. An LF was reached when flux could no longer be increased by increasing TMP. At this point, a fouled water flux was determined with $50^{\circ} \mathrm{C} \mathrm{RO}$ water and the $\mathrm{MF}$ system was cleaned as described by Hurt et al. (2010).

\section{Analytical Testing}

Proximate Analyses. Skim milk samples were collected before processing. Retentate and permeate samples were collected during processing and analyzed using a calibration for milk to rapidly estimate fat, anhydrous lactose, and true protein (TP) using MIR (Kaylegian et al., 2006). The MIR analysis was done to confirm that the retentate protein concentration remained near $8.5 \%$ during processing and to detect changes in SP passage in the permeate during a processing run. Skim milk TS, fat, total nitrogen (TN), NPN, and noncasein nitrogen (NCN) were determined using forced-air oven drying (AOAC International, 2000; method 990.20; 33.2.44), ether extraction (AOAC International, 2000; method 989.05; 33.2.26), Kjeldahl (AOAC International, 2000; method 991.20; 33.2.11), Kjeldahl (AOAC International, 2000; method 991.21; 33.2.12), and Kjeldahl (AOAC International, 2000; method 998.05; 33.2.64), respectively. Skim milk NCN preparation was modified by increasing the amounts of sodium acetate $(1 \mathrm{~N})$ and acetic acid $(10 \% \mathrm{vol} / \mathrm{vol})$ 
from $1 \mathrm{~mL}$ each to $5.5 \mathrm{~mL}$ each to fully precipitate casein (Wojciechowski and Barbano, 2015). Crude protein was calculated by multiplying $\mathrm{TN}$ by 6.38 , TP was calculated by subtracting NPN from TN and multiplying by 6.38 , casein was calculated by subtracting $\mathrm{NCN}$ from $\mathrm{TN}$ and multiplying by 6.38 , and $\mathrm{SP}$ content was calculated by subtracting NPN from NCN and multiplying by 6.38 . Retentate samples from each flux step were analyzed for TS, TN, and NPN using the same methods as the skim milk samples and TP was calculated. Permeate samples from each flux step were analyzed for TS, TN, NPN, and NCN using the same methods as the skim milk samples and TP, casein, and $\mathrm{SP}$ were calculated. The $\mathrm{pH}$ of the skim milk, permeates, and retentates were measured during processing with a solid polymer electrode (HA405-DXK-S8/120, Mettler-Toledo) and an Accumet $915 \mathrm{pH}$ meter (Fisher Scientific, Pittsburgh, PA) that was calibrated at $50^{\circ} \mathrm{C}$ using standard pH 4 and 7 buffer solutions (SB101, SB107, Fisher Scientific). All skim milk, permeate, and retentate TN, NPN, and NCN samples were immediately refrigerated at $<4^{\circ} \mathrm{C}$ and analyzed within $24 \mathrm{~h}$ of processing. All skim milk, permeate, and retentate $\mathrm{TS}$ and fat samples were immediately frozen at $-80^{\circ} \mathrm{C}$ until analysis.

Permeate SDS-PAGE. A 10 to $20 \%$ polyacrylamide gradient was used to determine the relative proportion of protein types in permeate samples from the initial flux $\left(45 \mathrm{~kg} \cdot \mathrm{m}^{-2} \cdot \mathrm{h}^{-1}\right)$ and the LF of the UTP round and UTP diamond treatments. Permeates $(0.1 \mathrm{~mL})$ were diluted with sample buffer $(0.9 \mathrm{~mL})$ consisting of 10 $\mathrm{m} M$ Tris- $\mathrm{HCl} \mathrm{pH} 6.8,1.0 \%$ SDS, $20 \%$ glycerol, $0.02 \%$ bromophenol blue tracking dye, and $50 \mathrm{~m} M$ dithiothreitol in glass vials (Target DP Vials C4000-1W, National Scientific Company, Rockwood, TN) and sealed with DP Blue Caps (C4000-51B, National Scientific Company). Diluted samples were heated to $100^{\circ} \mathrm{C}$ with steam, held at $100^{\circ} \mathrm{C}$ for 3 min, cooled to about $25^{\circ} \mathrm{C}$, and promptly frozen $\left(-17^{\circ} \mathrm{C}\right)$ until use. Twenty microliters of each prepared permeate sample was loaded onto the SDS-PAGE gel in duplicate from a common vial to achieve an optical density of the predominant protein in the sample in the range of 1.0 to 1.4. The procedure of Verdi et al. (1987) was used for running, staining, and destaining the gels. Gels were scanned with a USB GS 800 Densitometer using Quantity 1 1-D Analysis software (Bio-Rad Laboratories Inc., Hercules, CA) to obtain a relative protein composition of samples. One gel was prepared for each replicate. This layout was chosen to account for replicate error in the results during statistical analysis. A single skim milk sample (0.1 $\mathrm{mL}$ of skim milk in $0.9 \mathrm{~mL}$ of sample buffer with an $8.5-\mu \mathrm{L}$ loading volume) from the respective replicate was run on each gel as a reference for proper resolution of milk proteins and a check for consistency of quantitative analysis from gel to gel. The background was adjusted separately for each lane using the rolling disk method of subtraction to obtain a flat base on the popup trace. The line that defined each lane was adjusted using the lane tool function (add, adjust anchors) in the software so that the lane line crossed each band at the center. The adjust band function of the software was used with brackets to set the leading and trailing edge for each band as visually observed on the image of the gel, not based on the beginning and end of the peak in the pop-up trace. The bracket width was set to include the full width of all bands.

\section{SP and Permeate Removal Calculations}

SP Removal Factor. The SP removal factor for each flux step was estimated using Kjeldahl data of the pasteurized skim milk and permeates. The SP removal factor was calculated by dividing the permeate SP by the skim milk SP in the permeate portion of the skim milk $\left[\mathrm{SP}_{\text {Skim milk }} /\left(100-\mathrm{CN}_{\text {Skim milk }}\right) \times 100\right]$.

Modular Permeate Removal Rate. Modular permeate removal rates were calculated by multiplying the mass flux by the membrane module area $\left(1.41 \mathrm{~m}^{2}\right.$ for the round channel module and $2.07 \mathrm{~m}^{2}$ for the diamond channel module).

\section{Retentate Apparent Viscosity Measurement}

Apparent viscosities of all retentates were measured using a rotational viscometer (LV-DV2T, Brookfield Engineering Laboratories Inc., Middleboro, MA) equipped with a jacketed cup and bob fixture (Enhanced UL Adapter, Brookfield Engineering Laboratories Inc.). All samples were measured at $50 \pm 1^{\circ} \mathrm{C}$ at a constant shear rate of $73 \mathrm{~s}^{-1}$. Temperature was maintained by placing $16 \mathrm{~mL}$ of tempered sample into the cup and circulating $50^{\circ} \mathrm{C}$ water through the jacket during measurement. Each sample measurement reflected the average viscosity obtained under $30 \mathrm{~s}$ of shear after a 20-s shear equilibration period.

\section{Permeate Relative Whiteness Values}

Hunter L values (whiteness) for the permeates were determined in duplicate with a Macbeth Color-Eye spectrophotometer (model 2020; Kollmorgen Instruments, Corp., Newburgh, NY) with ProPalette software (Version 5.0; Kollmorgen Instruments Corp.). A white color tile was used as a reflectance standard and was measured at the beginning of each session to verify instrument performance. Hunter values were computed from the diffuse reflectance of light in the 360 to 750 
$\mathrm{nm}$ range, at $10-\mathrm{nm}$ intervals, based on illuminant $\mathrm{A}$. The measurements were made at $24 \pm 1^{\circ} \mathrm{C}$ using a 1 -cm path length glass cuvette. Because the permeates were transparent and the cuvette was placed against a black background, the $\mathrm{L}$ values should not be considered whiteness values, but rather relative whiteness values $\left(\mathbf{L}_{\mathrm{R}}\right)$.

A preliminary experiment was conducted in which varying levels of skim milk were added to MF permeates and the $L_{R}$ values were measured. The casein contributed to the permeates by the skim milk was calculated based on the weight and casein concentration of the skim milk (0 to $0.023 \% \mathrm{wt} / \mathrm{wt}$ added casein) and was highly correlated with the $\mathrm{L}_{\mathrm{R}}$ values of the permeates $\left(\mathrm{R}^{2}>0.99\right.$, data not shown). Consequently, higher $\mathrm{L}_{\mathrm{R}}$ values are indicative of higher levels of micellar casein in the MF permeate.

\section{Hydrodynamic Conditions}

Reynolds Numbers. The dimensionless Reynolds number (Re) indicates whether flow is turbulent $(>4,000)$ or laminar $(<2,100)$. Reynolds numbers were calculated for the retentates at each flux step according to Equation 1, where $\rho$ is the retentate density at $50^{\circ} \mathrm{C}$ $\left(1,040 \mathrm{~kg} \cdot \mathrm{m}^{-3}\right.$; Adams et al., 2015), $\mathrm{D}_{\mathrm{h}}$ is the membrane hydraulic diameter, $\mathrm{V}$ is the average retentate crossflow velocity $\left(\mathrm{m} \cdot \mathrm{s}^{-1}\right)$, and $\mu$ is the retentate viscosity at $50^{\circ} \mathrm{C}(\mathrm{Pa} \cdot \mathrm{s})$ :

$$
\operatorname{Re}=\frac{\rho D_{\mathrm{h}} \mathrm{V}}{\mu} .
$$

The round retentate flow channel, $\mathrm{D}_{\mathrm{h}}$, was the channel diameter $(0.004 \mathrm{~m})$. Because the diamond-shaped retentate flow channel $D_{h}$ was noncircular, it was calculated according to Equation 2 (Obot, 1988), where $\mathrm{A}$ is the cross sectional area $\left(\mathrm{m}^{2}\right)$ and $\mathrm{P}_{\mathrm{w}}$ is the wetted perimeter $(\mathrm{m})$ of the flow channel:

$$
\mathrm{D}_{\mathrm{h}}=\frac{4 \mathrm{~A}}{\mathrm{P}_{\mathrm{w}}}=\frac{4 \times\left[\frac{(0.0038 \times 0.0059)}{2}\right]}{0.014}=0.0032 .
$$

Computational Fluid Dynamics. The turbulent fluid flow analysis module of COMSOL Multiphysics (Version 4.3b, Stockholm, Sweden) was used to model radial velocity distributions in both the round and diamond-shaped retentate flow channels. Channel geometries were drawn in 3 dimensions using COMSOL and meshing was set to the fluid dynamics preset value of "finer." The Reynolds-averaged Navier-Stokes k- $\omega$ model parameters for constants used in the modeling were: $\alpha=0.52, \sigma_{\mathrm{k}}{ }^{*}=0.5, \sigma_{\omega}=0.5, \beta_{0}=0.072, \beta_{0}{ }^{*}$ $=0.09, \kappa_{\mathrm{v}}=0.41$, and $\mathrm{B}=5.2$. Assumptions included turbulent, stationary flow of an incompressible fluid with dynamic viscosity $=1.64 \mathrm{mPa} \cdot \mathrm{s}$ and density $=$ $1,040 \mathrm{~kg} \cdot \mathrm{m}^{-3}$. Because axial flow through the membrane channels (i.e., retentate cross-flow) was $280 \times$ the radial flow through the membrane channels (i.e., permeation through the membrane), radial flow was neglected. The channel inlet boundary condition was an average cross-flow velocity of $7 \mathrm{~m} \cdot \mathrm{s}^{-1}$ and the channel outlet boundary condition was a gauge pressure of 230 $\mathrm{kPa}$. A wall functions boundary condition was set at the wall. This approximated velocity near the wall and did not assume it to be equal to $0 \mathrm{~m} \cdot \mathrm{s}^{-1}$. This assumption reduces computational requirements and is a valid approach for practical engineering applications when flow is highly turbulent (COMSOL, 2013). A stationary iterative solver (400 iterations maximum) was used to solve the Navier-Stokes equations. Data were visualized by slicing a cross-sectional area from the center of each channel.

\section{Statistical Analysis}

Data were analyzed by ANOVA using the Proc GLM procedure of SAS (SAS version 9.4, SAS Institute Inc., Cary, NC). To detect differences $(P<0.05)$ in composition among skim milks used with the different membranes, the general linear model was dependent variable $=$ membrane + replicate + error, where replicate was considered a random variable. To detect differences $(P<0.05)$ in processing variables, retentates, and permeates among membranes and fluxes, the general linear model was dependent variable $=$ membrane + flux + replicate + membrane $\times$ flux + replicate $\times$ membrane + error, where replicate and replicate $x$ membrane were random variables. Because membrane was a whole-plot factor in the split block design, its significance was tested using replicate $\times$ membrane as the error term. For comparisons of least squares means among the membranes and fluxes, a Tukey-Kramer adjustment was made for multiple comparisons.

\section{RESULTS AND DISCUSSION}

\section{Proximate Compositions of Skim Milk, Retentates, and Permeates}

Skim Milk Composition. The mean compositions of the skim milks used to feed the 3 systems are shown in Table 1. The mean casein/TP percent of the raw skim milk $(80.2 \pm 0.1 \%)$ was slightly lower $(P<0.05)$ 
Table 1. Mean $(\mathrm{n}=3)$ compositions of skim milks used to feed the round channel without uniform transmembrane pressure (UTP), round channel with UTP, and diamond channel with UTP microfiltration processes $^{1}$

\begin{tabular}{lccccc}
\hline Item & $\begin{array}{c}\text { Round } \\
\text { No UTP }\end{array}$ & $\begin{array}{c}\text { Round } \\
\text { UTP }\end{array}$ & $\begin{array}{c}\text { Diamond } \\
\text { UTP }\end{array}$ & SE & $\mathrm{R}^{2}$ \\
\hline TS (\%) & 9.237 & 9.225 & 9.223 & 0.017 & 0.96 \\
Fat (\%) & 0.119 & 0.124 & 0.127 & 0.005 & 0.52 \\
CP (\%) & 3.411 & 3.415 & 3.417 & 0.007 & 0.99 \\
NPN $\times 6.38(\%)$ & 0.174 & 0.172 & 0.175 & 0.004 & 0.83 \\
Noncasein N $\times$ 6.38 (\%) & 0.796 & 0.807 & 0.799 & 0.005 & 0.87 \\
True protein (\%) & 3.237 & 3.243 & 3.242 & 0.008 & 0.98 \\
Casein (\%) & 2.615 & 2.608 & 2.618 & 0.012 & 0.95 \\
Serum protein (\%) & 0.622 & 0.635 & 0.624 & 0.007 & 0.90 \\
SP permeateportion $^{2}(\%)$ & 0.639 & 0.652 & 0.641 & 0.007 & 0.90 \\
CN\% TP $^{3}(\%)$ & 80.79 & 80.42 & 80.75 & 0.221 & 0.74 \\
pH $^{4}$ & 6.47 & 6.45 & 6.47 & 0.014 & 0.84 \\
\hline
\end{tabular}

${ }^{1}$ Means within the same row are not different $(P>0.05)$.

${ }^{2} \mathrm{SP}_{\text {permeate portion }}=[$ serum protein $/(100-$ casein $)]$.

${ }^{3} \mathrm{CN} \% \mathrm{TP}=($ casein $/$ true protein $) \times 100$.

${ }^{4} \mathrm{pH}$ measured at $50^{\circ} \mathrm{C}$.

than that of the pasteurized skim milk. This indicated that some SP was bound to the CN micelles due to heat denaturation of SP during pasteurization, but the level was low. No differences $(P>0.05)$ in composition were detected among the skim milks used to feed the 3 systems (Table 1).

Membrane Geometry Comparison: Retentate Composition. The mean compositions of retentates produced using the round channel system with UTP and diamond channel system with UTP at 45 and 65 $\mathrm{kg} \cdot \mathrm{m}^{-2} \cdot \mathrm{h}^{-1}$ and the LF are shown in Table 2. Retentate $\mathrm{CP}$ and TP were higher $(P<0.05)$ for the round channel system at the initial flux. The retentate flow rate was lowest under these conditions (i.e., $45 \mathrm{~kg} \cdot \mathrm{m}^{-2} \cdot \mathrm{h}^{-1}$, round channel system), the accuracy of the flow meter may have been reduced in this range. Thus, we may not have been able control CF as accurately at this retentate removal rate, resulting in a slightly higher $\mathrm{CP}$ and TP concentrations. However, differences in TP between the systems at the initial flux were low $(<0.4 \%)$ and no differences $(P>0.05)$ in composition were detected between systems at the LF. Differences in TS were consistent with the differences detected in $\mathrm{CP}$ and TP. Retentate NPN was slightly higher $(P<0.05)$ at the LF than at the lower fluxes for both systems. No differences $(P>0.05)$ in retentate $\mathrm{pH}$ were detected among any of the conditions tested.

Membrane Geometry Comparison: Permeate Composition. The mean compositions of permeates produced using the round channel system with UTP and diamond channel system with UTP at 45 and 65 $\mathrm{kg} \cdot \mathrm{m}^{-2} \cdot \mathrm{h}^{-1}$ and the LF are shown in Table 3. Permeate $\mathrm{CP}$ and TP were highest $(P<0.05)$ in the diamond channel system at each flux. No changes $(P>0.05)$ in $\mathrm{CP}$ or TP (Figure 2) were observed in the diamond channel system, as flux was increased because the decrease $(P<0.05)$ in SP from $65 \mathrm{~kg} \cdot \mathrm{m}^{-2} \cdot \mathrm{h}^{-1}$ to the $\mathrm{LF}$ was balanced by an increase $(P<0.05)$ in casein (Table $3)$; the decrease in SP was caused by membrane fouling. The increase in casein was caused by enhanced casein concentration near the membrane surface at higher fluxes. Permeate CP (Table 3), TP (Figure 2 and Table $3)$, and SP (Table 3) in the round channel system decreased $(P<0.05)$ as the flux was increased from

Table 2. Mean $\left(\mathrm{n}=3\right.$ ) compositions ${ }^{1}$ of retentates at 45 and $65 \mathrm{~kg} \cdot \mathrm{m}^{-2} \cdot \mathrm{h}^{-1}$ and at the limiting flux $(\mathrm{LF})^{2}$ when microfiltering skim milk using $4-\mathrm{mm}$ round channel membranes or $4-\mathrm{mm}$ equivalent diameter diamond-shaped channel membranes at $50^{\circ} \mathrm{C}$

\begin{tabular}{|c|c|c|c|c|c|c|c|c|}
\hline Item & $\begin{array}{c}\text { Round } \\
45\end{array}$ & $\begin{array}{c}\text { Round } \\
65\end{array}$ & $\begin{array}{l}\text { Round } \\
\text { LF }\end{array}$ & $\begin{array}{l}\text { Diamond } \\
45\end{array}$ & $\begin{array}{l}\text { Diamond } \\
\quad 65\end{array}$ & $\begin{array}{l}\text { Diamond } \\
\text { LF }\end{array}$ & $\mathrm{SE}$ & $\mathrm{R}^{2}$ \\
\hline$\overline{\mathrm{TS}(\%)}$ & $15.044^{\mathrm{a}}$ & $14.739^{\mathrm{b}}$ & $14.770^{\mathrm{b}}$ & $14.711^{\mathrm{b}}$ & $14.687^{\mathrm{b}}$ & $14.696^{\mathrm{b}}$ & 0.084 & 0.85 \\
\hline $\mathrm{CP}(\%)$ & $8.999^{\mathrm{a}}$ & $8.667^{\mathrm{b}}$ & $8.611^{\mathrm{b}}$ & $8.654^{\mathrm{b}}$ & $8.575^{\mathrm{b}}$ & $8.573^{\mathrm{b}}$ & 0.088 & 0.87 \\
\hline $\mathrm{TP}(\%)$ & $8.837^{\mathrm{a}}$ & $8.503^{b}$ & $8.435^{\mathrm{b}}$ & $8.488^{\mathrm{b}}$ & $8.412^{\mathrm{b}}$ & $8.396^{\mathrm{b}}$ & 0.088 & 0.88 \\
\hline $\mathrm{pH}$ & 6.44 & 6.44 & 6.44 & 6.46 & 6.46 & 6.46 & 0.003 & 0.99 \\
\hline
\end{tabular}

${ }^{\mathrm{a}, \mathrm{b}}$ Means within the same row not followed by the same letter are different $(P<0.05)$.

${ }^{1} \mathrm{NPN}=\mathrm{NPN} \times 6.38 ; \mathrm{TP}($ true protein $)=\mathrm{CP}-\mathrm{NPN}$.

${ }^{2}$ Mean round and diamond channel membrane LF were 88 and $71 \mathrm{~kg} \cdot \mathrm{m}^{-2} \cdot \mathrm{h}^{-1}$, respectively. 
Table 3. Mean $(\mathrm{n}=3)$ compositions $^{1}$ of permeates at 45 and $65 \mathrm{~kg} \cdot \mathrm{m}^{-2} \cdot \mathrm{h}^{-1}$ and at the limiting flux $(\mathrm{LF})^{2}$ when microfiltering skim milk using 4-mm round channel membranes or 4-mm equivalent diameter diamond-shaped channel membranes at $50^{\circ} \mathrm{C}$

\begin{tabular}{|c|c|c|c|c|c|c|c|c|}
\hline Item & $\begin{array}{c}\text { Round } \\
45\end{array}$ & $\begin{array}{c}\text { Round } \\
65\end{array}$ & $\begin{array}{l}\text { Round } \\
\text { LF }\end{array}$ & $\begin{array}{c}\text { Diamond } \\
45\end{array}$ & $\begin{array}{c}\text { Diamond } \\
65\end{array}$ & $\begin{array}{c}\text { Diamond } \\
\text { LF }\end{array}$ & $\mathrm{SE}$ & $\mathrm{R}^{2}$ \\
\hline$\overline{\mathrm{TS}(\%)}$ & $6.407^{\mathrm{ab}}$ & $6.403^{\mathrm{ab}}$ & $6.318^{\mathrm{c}}$ & $6.439^{\mathrm{a}}$ & $6.433^{\mathrm{a}}$ & $6.374^{\mathrm{bc}}$ & 0.019 & 0.92 \\
\hline $\mathrm{CP}(\%)$ & $0.695^{\mathrm{b}}$ & $0.684^{\mathrm{b}}$ & $0.642^{\mathrm{c}}$ & $0.733^{\mathrm{a}}$ & $0.736^{\mathrm{a}}$ & $0.728^{\mathrm{a}}$ & 0.007 & 0.98 \\
\hline $\operatorname{NPN}(\%)$ & 0.170 & 0.169 & 0.170 & 0.170 & 0.170 & 0.166 & 0.003 & 0.85 \\
\hline $\operatorname{NCN}(\%)$ & $0.694^{\mathrm{b}}$ & $0.684^{\mathrm{b}}$ & $0.637^{\mathrm{c}}$ & $0.723^{\mathrm{a}}$ & $0.712^{\mathrm{a}}$ & $0.687^{\mathrm{b}}$ & 0.005 & 0.98 \\
\hline $\mathrm{TP}(\%)$ & $0.525^{\mathrm{b}}$ & $0.515^{\mathrm{b}}$ & $0.472^{\mathrm{c}}$ & $0.562^{\mathrm{a}}$ & $0.566^{\mathrm{a}}$ & $0.561^{\mathrm{a}}$ & 0.007 & 0.98 \\
\hline $\mathrm{CN}(\%)$ & $0.001^{\mathrm{c}}$ & $0.001^{\mathrm{c}}$ & $0.006^{\mathrm{c}}$ & $0.010^{\mathrm{bc}}$ & $0.024^{\mathrm{b}}$ & $0.040^{\mathrm{a}}$ & 0.006 & 0.94 \\
\hline $\mathrm{SP}(\%)$ & $0.524^{\mathrm{b}}$ & $0.515^{\mathrm{b}}$ & $0.467^{\mathrm{c}}$ & $0.553^{\mathrm{a}}$ & $0.543^{\mathrm{a}}$ & $0.521^{\mathrm{b}}$ & 0.005 & 0.99 \\
\hline $\mathrm{pH}$ & 6.50 & 6.50 & 6.50 & 6.52 & 6.52 & 6.52 & 0.004 & 0.98 \\
\hline
\end{tabular}

${ }^{\mathrm{a}-\mathrm{c}}$ Means within the same row not followed by the same letter are different $(P<0.05)$.

${ }^{1} \mathrm{NPN}=\mathrm{NPN} \times 6.38 ; \mathrm{NCN}=$ noncasein $\mathrm{N} \times 6.38 ; \mathrm{TP}($ true protein $)=\mathrm{CP}-\mathrm{NPN} ; \mathrm{CN}=\mathrm{TP}-\mathrm{NCN} ; \mathrm{SP}($ serum protein) $=\mathrm{NCN}-\mathrm{NPN}$.

${ }^{2}$ Mean round and diamond channel membrane $\mathrm{LF}$ were 88 and $71 \mathrm{~kg} \cdot \mathrm{m}^{-2} \cdot \mathrm{h}^{-1}$, respectively.

$65 \mathrm{~kg} \cdot \mathrm{m}^{-2} \cdot \mathrm{h}^{-1}$ to the $\mathrm{LF}$ due to membrane fouling. No changes $(P>0.05)$ in permeate casein were observed among flux steps in the round channel system. Permeate casein in the diamond channel system was higher $(P$ $<0.05)$ than it was in the round channel system at 65 $\mathrm{kg} \cdot \mathrm{m}^{-2} \cdot \mathrm{h}^{-1}$ and the $\mathrm{LF}$. The difference in casein passage between the round and diamond-shaped flow channel membranes could have been caused by variation in the membrane selective layer coating due to the different geometries, differences in pore size distribution due to random variation in manufacturing tolerances, damage to the diamond channel membrane selective layer, or a combination of these factors. Permeate TS were highest $(P<0.05)$ for all fluxes in the diamond channel system

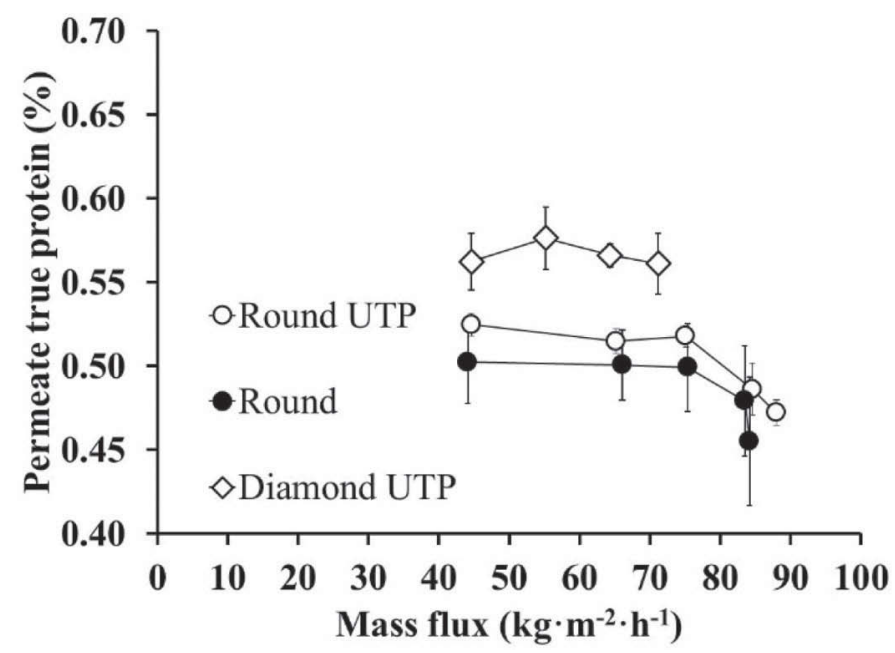

Figure 2. Mean $(\mathrm{n}=3)$ permeate true protein as a function of mass flux when microfiltering skim milk using 4-mm round channel membranes with and without uniform transmembrane pressure (UTP) and 4-mm equivalent diameter diamond channel membranes with UTP. Temperature $=50^{\circ} \mathrm{C}$; average cross-flow velocity $=7 \mathrm{~m} \cdot \mathrm{s}^{-1}$. Error bars represent \pm 1 SD. and decreased $(P<0.05)$ as flux was increased from 65 $\mathrm{kg} \cdot \mathrm{m}^{-2} \cdot \mathrm{h}^{-1}$ to the LF in the round channel system due to the differences in TP caused by fouling. No differences $(P>0.05)$ in NPN or $\mathrm{pH}$ were detected among any of the channel geometry or flux combinations.

UTP Comparison Retentate Composition. The mean compositions of retentates produced using the round channel membranes with and without UTP at 45 and $65 \mathrm{~kg} \cdot \mathrm{m}^{-2} \cdot \mathrm{h}^{-1}$ and the LF are shown in Table 4. Retentate $\mathrm{CP}$ and TP were higher $(P<0.05)$ at the initial flux (i.e., $45 \mathrm{~kg} \cdot \mathrm{m}^{-2} \cdot \mathrm{h}^{-1}$ ) than higher fluxes for both systems. As described above, this may have been due to reduced accuracy of the retentate flow meter at lower flow rates. Differences in TP between systems at the initial flux were low $(<0.4 \%)$ and no differences $(P$ $>0.05)$ in composition were detected between systems at the LF. Differences in TS were consistent with the differences detected in $\mathrm{CP}$ and TP. Retentate NPN was slightly higher $(P<0.05)$ at the LF than at the lower fluxes for the UTP system. No differences $(P>0.05)$ in retentate $\mathrm{pH}$ were detected among any of the conditions tested.

UTP Comparison Permeate Composition. The mean compositions of permeates produced using the round channel membranes with and without UTP at 45 and $65 \mathrm{~kg} \cdot \mathrm{m}^{-2} \cdot \mathrm{h}^{-1}$ and the LF are shown in Table 5 . At any given flux, no differences $(P>0.05)$ in permeate composition were observed between the systems. This indicated that the use of UTP had no effect on the composition of the permeate when round channel membranes were used. Preliminary work was done in which the diamond channel membranes were also operated with and without UTP. No effect of UTP on permeate composition was observed with the diamond channel membranes (data not shown). Permeate TS, CP, TP (Figure 2), NCN, and SP all decreased $(P<0.05)$ as flux was increased from $65 \mathrm{~kg} \cdot \mathrm{m}^{-2} \cdot \mathrm{h}^{-1}$ to the $\mathrm{LF}$ due to membrane fouling. No changes $(P>0.05)$ in NPN 
Table 4. Mean $(\mathrm{n}=3)$ compositions $^{1}$ of retentates at 45 and $65 \mathrm{~kg} \cdot \mathrm{m}^{-2} \cdot \mathrm{h}^{-1}$ and at the limiting flux $(\mathrm{LF})^{2}$ when microfiltering skim milk using 4 -mm round channel membranes with or without uniform transmembrane pressure (UTP) at $50^{\circ} \mathrm{C}$

\begin{tabular}{|c|c|c|c|c|c|c|c|c|}
\hline Item & $\begin{array}{c}\text { UTP } \\
45\end{array}$ & $\begin{array}{c}\text { UTP } \\
65\end{array}$ & $\begin{array}{l}\text { UTP } \\
\text { LF }\end{array}$ & $\begin{array}{c}\text { No UTP } \\
45\end{array}$ & $\begin{array}{c}\text { No UTP } \\
65\end{array}$ & $\begin{array}{l}\text { No UTP } \\
\text { LF }\end{array}$ & $\mathrm{SE}$ & $\mathrm{R}^{2}$ \\
\hline TS (\%) & $15.044^{\mathrm{a}}$ & $14.739^{\mathrm{b}}$ & $14.770^{\mathrm{b}}$ & $14.982^{\mathrm{a}}$ & $14.831^{\mathrm{b}}$ & $14.774^{\mathrm{b}}$ & 0.155 & 0.62 \\
\hline $\mathrm{TP}(\%)$ & $8.837^{\mathrm{a}}$ & $8.503^{\mathrm{b}}$ & $8.435^{\mathrm{b}}$ & $8.711^{\mathrm{a}}$ & $8.525^{\mathrm{b}}$ & $8.414^{\mathrm{b}}$ & 0.144 & 0.73 \\
\hline $\mathrm{pH}$ & 6.44 & 6.44 & 6.44 & 6.46 & 6.45 & 6.46 & 0.004 & 0.97 \\
\hline
\end{tabular}

${ }^{\mathrm{a}, \mathrm{b}}$ Means within the same row not followed by the same letter are different $(P<0.05)$.

${ }^{1} \mathrm{NPN}=$ nonprotein $\mathrm{N} \times 6.38 ; \mathrm{TP}($ true protein $)=\mathrm{CP}-\mathrm{NPN}$.

${ }^{2}$ Mean LF with and without UTP were 88 and $84 \mathrm{~kg} \cdot \mathrm{m}^{-2} \cdot \mathrm{h}^{-1}$, respectively.

or $\mathrm{pH}$ were observed among any of the UTP or flux combinations.

\section{Permeate SDS-PAGE and Color}

An SDS-PAGE was used to determine the relative quantities of proteins in permeates produced using the round channel membranes with UTP and diamond channel membranes with UTP at $45 \mathrm{~kg} \cdot \mathrm{m}^{-2} \cdot \mathrm{h}^{-1}$ and at the LF (Figure 3). The SDS-PAGE results were consistent with Kjeldahl analyses, and permeates produced using the diamond channel membranes at the LF contained more $(P<0.05)$ casein than any of the other permeates. No differences $(P>0.9)$ in casein were observed between fluxes when the round channel system was examined. No differences $(P=0.11)$ in casein were observed between membranes at the initial flux.

Differences in permeate casein content were associated with differences in permeate opacity. Skim milk is white because casein micelles scatter light. The presence of these micelles, even in small amounts, can increase the opacity of MF permeates. Figure 4 shows the $L_{R}$ values of the permeates produced using the 3 systems at all fluxes. Higher $L_{R}$ values indicate increased opacity in MF permeates that should be clear. The diamond channel system produced permeates with higher $(P<$ 0.05) $\mathrm{L}_{\mathrm{R}}$ values. Zulewska et al. (2009) determined MF permeate $L_{R}$ values by the same method and detected higher levels of casein in permeates when $L_{R} \geq 20$. All permeates produced using the diamond channel system in the present study had $L_{R}$ values above 20 . All permeates produced using the round channel system in the present study had $\mathrm{L}_{\mathrm{R}}$ values below 20. As flux was increased in the diamond channel system, $\mathrm{L}_{\mathrm{R}}$ values also increased $(P<0.05)$, indicating higher casein micelle passage through the membrane. These differences in opacity were easily detected visually (Figure $5)$. Increased casein passage into the permeate could potentially change the functional properties of any ingredient produced from the MF permeates (i.e., an SP concentrate).

\section{Apparent Viscosities of Retentates}

Retentate apparent viscosities ( shear rate $=73 \mathrm{~s}^{-1}$ ) at $50^{\circ} \mathrm{C}$ for the membrane geometry comparison and UTP comparison are shown in Tables 6 and 7 , respectively. Retentate produced with the round channel system at the initial flux had a higher $(P<0.05)$ viscosity than retentates produced using the round channel system

Table 5. Mean $(\mathrm{n}=3)$ compositions ${ }^{1}$ of permeates at 45 and $65 \mathrm{~kg} \cdot \mathrm{m}^{-2} \cdot \mathrm{h}^{-1}$ and at the limiting flux $(\mathrm{LF})^{2}$ when microfiltering skim milk using $4-\mathrm{mm}$ round channel membranes with or without uniform transmembrane pressure (UTP) at $50^{\circ} \mathrm{C}$

\begin{tabular}{|c|c|c|c|c|c|c|c|c|}
\hline Item & $\begin{array}{c}\text { UTP } \\
45\end{array}$ & $\begin{array}{c}\text { UTP } \\
65\end{array}$ & $\begin{array}{l}\text { UTP } \\
\text { LF }\end{array}$ & $\begin{array}{c}\text { No UTP } \\
45\end{array}$ & $\begin{array}{c}\text { No UTP } \\
65\end{array}$ & $\begin{array}{c}\text { No UTP } \\
\text { LF }\end{array}$ & $\mathrm{SE}$ & $\mathrm{R}^{2}$ \\
\hline$\overline{\mathrm{TS}(\%)}$ & $6.407^{\mathrm{a}}$ & $6.403^{\mathrm{a}}$ & $6.318^{\mathrm{b}}$ & $6.386^{\mathrm{a}}$ & $6.398^{\mathrm{a}}$ & $6.324^{\mathrm{b}}$ & 0.016 & 0.94 \\
\hline $\mathrm{CP}(\%)$ & $0.695^{\mathrm{a}}$ & $0.684^{\mathrm{a}}$ & $0.642^{\mathrm{b}}$ & $0.673^{\mathrm{a}}$ & $0.670^{\mathrm{a}}$ & $0.631^{\mathrm{b}}$ & 0.009 & 0.95 \\
\hline $\operatorname{NCN}(\%)$ & $0.694^{\mathrm{a}}$ & $0.684^{\mathrm{a}}$ & $0.637^{\mathrm{b}}$ & $0.667^{\mathrm{a}}$ & $0.665^{\mathrm{a}}$ & $0.626^{\mathrm{b}}$ & 0.008 & 0.97 \\
\hline $\mathrm{TP}(\%)$ & $0.525^{\mathrm{a}}$ & $0.515^{\mathrm{a}}$ & $0.472^{\mathrm{b}}$ & $0.503^{\mathrm{a}}$ & $0.501^{\mathrm{a}}$ & $0.455^{\mathrm{b}}$ & 0.007 & 0.97 \\
\hline $\mathrm{CN}(\%)$ & 0.001 & 0.001 & 0.006 & 0.005 & 0.005 & 0.005 & 0.004 & 0.79 \\
\hline
\end{tabular}

\footnotetext{
${ }^{\mathrm{a}, \mathrm{b}}$ Means within the same row not followed by the same letter are different $(P<0.05)$.

${ }^{1} \mathrm{NPN}=$ nonprotein $\mathrm{N} \times 6.38 ; \mathrm{NCN}=$ noncasein $\mathrm{N} \times 6.38 ; \mathrm{TP}($ true protein $)=\mathrm{CP}-\mathrm{NPN} ; \mathrm{CN}=\mathrm{TP}-\mathrm{NCN} ; \mathrm{SP}($ serum protein $)=\mathrm{NCN}-$ NPN.
}

${ }^{2}$ Mean LF with and without UTP were 88 and $84 \mathrm{~kg} \cdot \mathrm{m}^{-2} \cdot \mathrm{h}^{-1}$, respectively. 


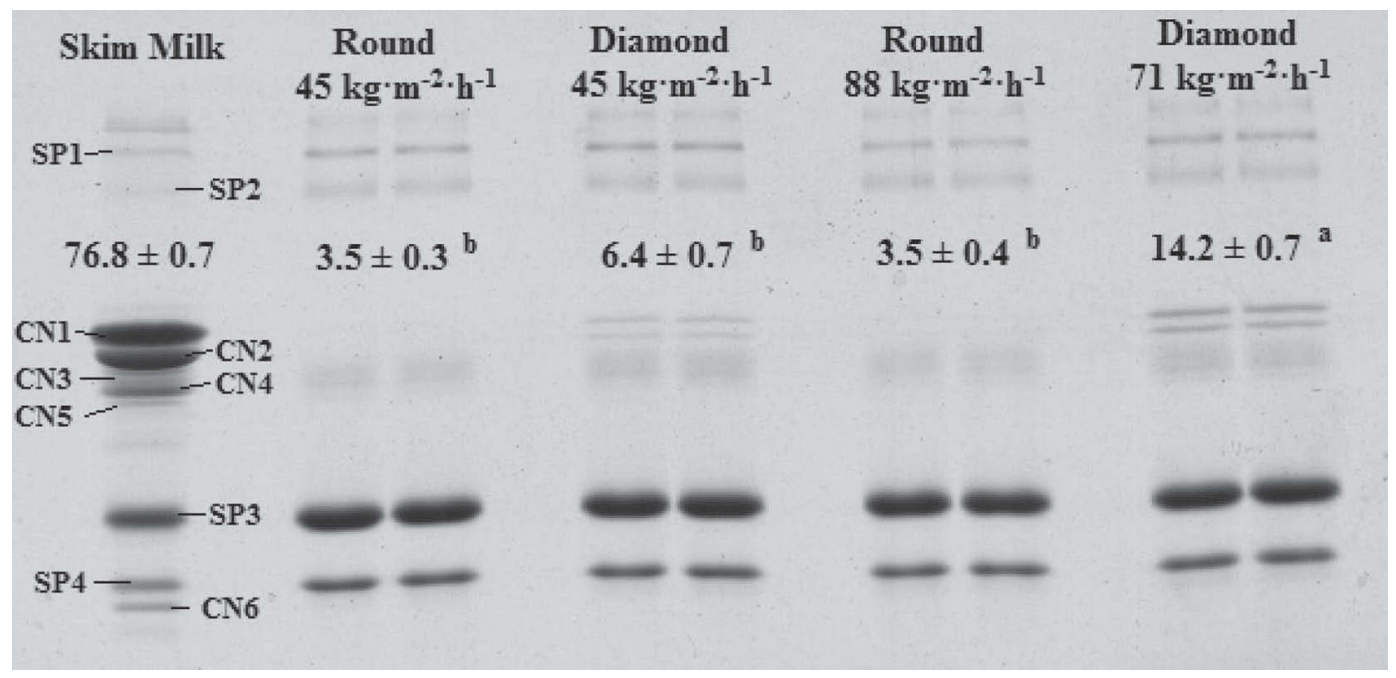

Figure 3. Proteins in skim milk and the microfiltration permeates produced using round channel retentate flow channel and diamond-shaped retentate flow channel membranes with uniform transmembrane pressure at $45 \mathrm{~kg} \cdot \mathrm{m}^{-2} \cdot \mathrm{h}^{-1}$ and the limiting fluxes as determined by SDS-PAGE. Bands in skim milk are identified on the gel as follows: SP1, SP2 = serum proteins; $\mathrm{CN} 1=\alpha_{\mathrm{s}}$ - CN $\left(\right.$ combination of $\alpha_{\mathrm{s} 1}{ }^{-}$and $\left.\alpha_{\mathrm{s} 2}{ }^{-} \mathrm{CN}\right)$; $\mathrm{CN} 2=$ $\beta-\mathrm{CN}$; CN4 = -CN ; CN3, CN5, and CN6 = proteolysis products of CN; SP3 = $\beta$-LG; and SP4 = $\alpha$-LA. Mean (n $=6)$ sums of all CN bands (\% relative density) are shown for each membrane, flux combination \pm SE. Means not followed by the same letter are different $(P<0.05)$.

at the LF or using the diamond channel system at the initial flux (Table 6). These differences were associated with differences in TP concentrations as described above (Table 2); however, no differences $(P>0.05)$ in viscosity were detected between the membrane systems at the LF (Table 6). No differences $(P>0.05)$ in viscosity were detected among the retentates produced by the round channel membranes with or without UTP at any flux (Table 7).

\section{MF Processing Data}

Mean temperature and CF among all treatments were $50 \pm 0.2^{\circ} \mathrm{C}$ and $2.98 \pm 0.09$ times, respectively, and no differences were detected among membrane or UTP treatments or fluxes $(P>0.05$; data not shown).

Membrane Geometry Comparison Pressures. Mean process gauge pressures for the round and diamond channel systems are shown in Table 8. The diamond-shaped channels in our study were designed to have an equivalent diameter of a round 4-mm flow channel. Noncircular channels with diameters which are equivalent to a given round channel's diameter should yield the same pressure drop per unit channel length at a given average cross-flow velocity. The $\mathrm{P}_{\mathrm{Ri}}$ for the round channel system was higher $(P<0.05)$ than $\mathrm{P}_{\mathrm{Ri}}$ for the diamond channel system (Table 8 ). Because no differences $(P>0.05)$ in $\mathrm{P}_{\mathrm{Ro}}$ were observed between the systems, $\Delta \mathrm{P}$ differences followed $\mathrm{P}_{\mathrm{Ri}}$ differences and were higher $(P<0.05)$ for the round channel system. These differences were small $(\Delta \mathrm{P}$ about $2 \%$ higher for round channel membranes), as would be expected of membranes with the same equivalent diameter. No differences in $\mathrm{P}_{\mathrm{Pi}}, \mathrm{P}_{\mathrm{Po}}, \mathrm{TMP}_{\mathrm{i}}$, or $\mathrm{TMP}_{\mathrm{o}}$ were observed between the systems at the initial flux. However, $\mathrm{P}_{\mathrm{Pi}}$ and $\mathrm{P}_{\mathrm{Po}_{\mathrm{o}}}$ were lower $(P<0.05)$ and $\mathrm{TMP}_{\mathrm{i}}$ and $\mathrm{TMP}_{\mathrm{o}}$ were higher $(P<0.05)$ in the diamond channel system at $65 \mathrm{~kg} \cdot \mathrm{m}^{-2} \cdot \mathrm{h}^{-1}$. Given the similarities in $\mathrm{P}_{\mathrm{Ri}}$ and $\mathrm{P}_{\mathrm{Ro}}$ between the 2 systems, this indicated that the diamond channel system was fouling to a greater degree than the

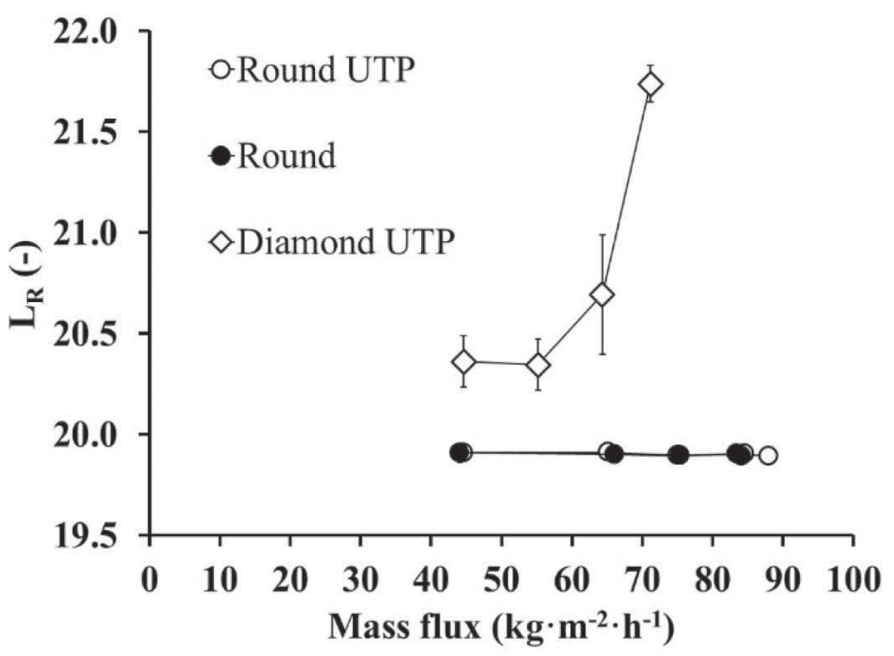

Figure 4. Mean $(\mathrm{n}=3)$ permeate relative whiteness $\left(\mathrm{L}_{\mathrm{R}}\right)$ values (measured at $24^{\circ} \mathrm{C}$ ) as a function of mass flux when microfiltering skim milk using 4-mm round channel membranes with and without uniform transmembrane pressure (UTP) and 4-mm equivalent diameter diamond channel membranes with UTP. Error bars represent \pm 1 SD. 


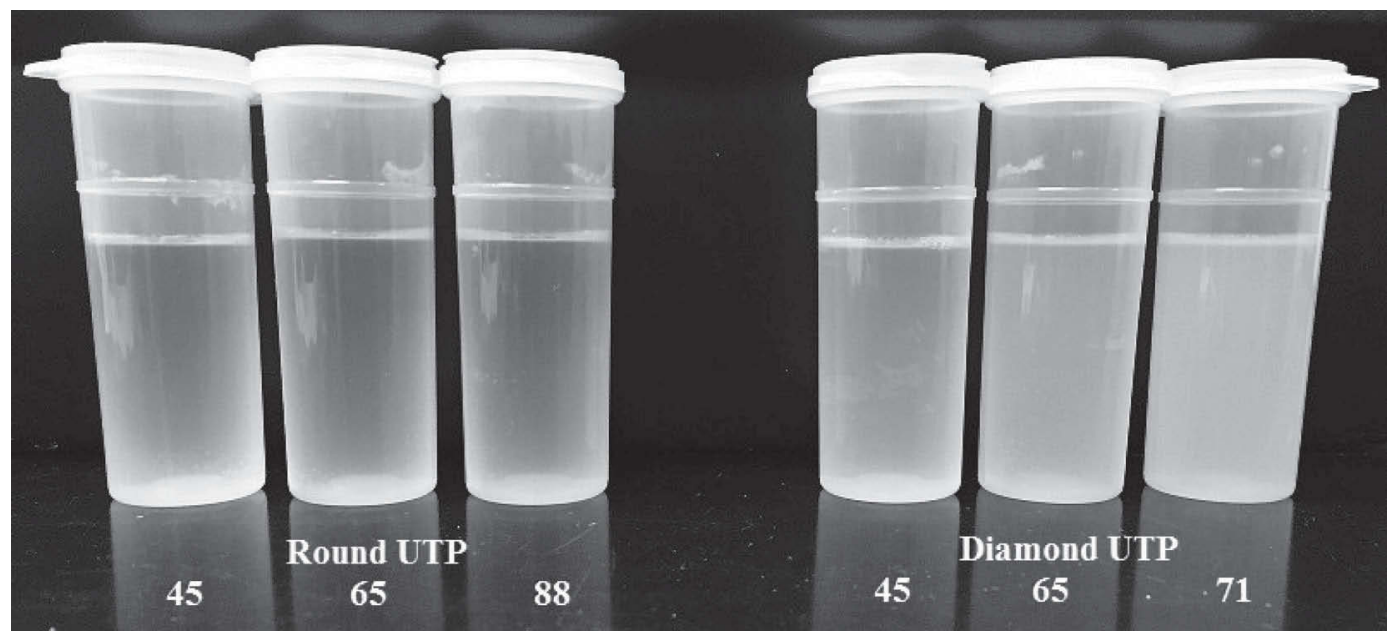

Figure 5. Microfiltration permeates produced from skim milk using 4-mm round channel membranes with uniform transmembrane pressure (UTP) and 4-mm equivalent diameter diamond channel membranes with UTP at fluxes of $45 \mathrm{~kg} \cdot \mathrm{m}^{-2} \cdot \mathrm{h}^{-1}, 65 \mathrm{~kg} \cdot \mathrm{m}^{-2} \cdot \mathrm{h}^{-1}$, and the limiting flux. Limiting fluxes for round with UTP and diamond with UTP were 88 and $71 \mathrm{~kg} \cdot \mathrm{m}^{-2} \cdot \mathrm{h}^{-1}$, respectively

Table 6. Mean $\left(\mathrm{n}=3\right.$ ) retentate flow dynamic data at 45 and $65 \mathrm{~kg} \cdot \mathrm{m}^{-2} \cdot \mathrm{h}^{-1}$ and the limiting flux $(\mathrm{LF})^{1}$ when microfiltering skim milk using $4-\mathrm{mm}$ round channel membranes or 4 -mm equivalent diameter diamond-shaped channel membranes at $50^{\circ} \mathrm{C}$

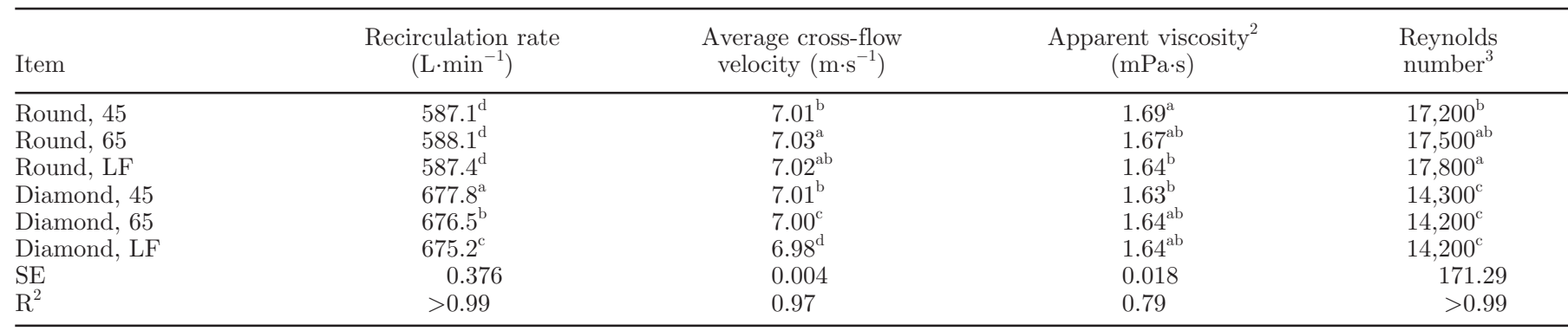

${ }^{\mathrm{a}-\mathrm{d}}$ Means within the same column not followed by the same letter are different $(P<0.05)$.

${ }^{1}$ Mean round and diamond channel membrane LF were 88 and $71 \mathrm{~kg} \cdot \mathrm{m}^{-2} \cdot \mathrm{h}^{-1}$, respectively.

${ }^{2}$ Apparent viscosity at $50^{\circ} \mathrm{C}, 73 \mathrm{~s}^{-1}$.

${ }^{3}$ Reynolds number $=$ density $\left(1,040 \mathrm{~kg} \cdot \mathrm{m}^{-3}\right) \times$ hydraulic diameter (round $=0.004 \mathrm{~m}$, diamond $\left.=0.0032 \mathrm{~m}\right) \times$ average cross-flow velocity $\left(\mathrm{m} \cdot \mathrm{s}^{-1}\right) /$ retentate viscosity $(\mathrm{Pa} \cdot \mathrm{s})$.

Table 7. Mean $(\mathrm{n}=3)$ retentate flow dynamic data at 45 and $65 \mathrm{~kg} \cdot \mathrm{m}^{-2} \cdot \mathrm{h}^{-1}$ and the limiting flux $(\mathrm{LF})^{1}$ when microfiltering skim milk using 4 -mm round channel membranes with or without uniform transmembrane pressure (UTP) at $50^{\circ} \mathrm{C}^{2}$

\begin{tabular}{|c|c|c|c|c|}
\hline Item & $\begin{array}{l}\text { Recirculation rate } \\
\left(\mathrm{L} \cdot \mathrm{min}^{-1}\right)\end{array}$ & $\begin{array}{l}\text { Average cross-flow } \\
\text { velocity }\left(\mathrm{m} \cdot \mathrm{s}^{-1}\right)\end{array}$ & $\begin{array}{c}\text { Apparent viscosity } \\
(\mathrm{mPa} \cdot \mathrm{s})\end{array}$ & $\begin{array}{l}\text { Reynolds } \\
\text { number }^{4}\end{array}$ \\
\hline UTP, 45 & 587.1 & 7.01 & 1.69 & 17,200 \\
\hline UTP, 65 & 588.1 & 7.03 & 1.67 & 17,500 \\
\hline No UTP, 45 & 587.4 & 7.02 & 1.68 & 17,400 \\
\hline No UTP, 65 & 586.4 & 7.01 & 1.67 & 17,500 \\
\hline No UTP, LF & 586.5 & 7.01 & 1.65 & 17,600 \\
\hline
\end{tabular}

${ }^{1}$ Mean LF with and without UTP were 88 and $84 \mathrm{~kg} \cdot \mathrm{m}^{-2} \cdot \mathrm{h}^{-1}$, respectively.

${ }^{2}$ Means within the same column are not different $(P>0.05)$.

${ }^{3}$ Apparent viscosity at $50^{\circ} \mathrm{C}, 73 \mathrm{~s}^{-1}$.

${ }^{4}$ Reynolds number $=$ density $\left(1,040 \mathrm{~kg} \cdot \mathrm{m}^{-3}\right) \times$ hydraulic diameter (round $=0.004 \mathrm{~m}$, diamond $\left.=0.0032 \mathrm{~m}\right) \times$ average cross-flow velocity $\left(\mathrm{m} \cdot \mathrm{s}^{-1}\right) /$ retentate viscosity $(\mathrm{Pa} \cdot \mathrm{s})$. 
Table 8. Mean $(\mathrm{n}=3)$ gauge pressures ${ }^{1}(\mathrm{kPa})$ at 45 and $65 \mathrm{~kg} \cdot \mathrm{m}^{-2} \cdot \mathrm{h}^{-1}$, and limiting fluxes $(\mathrm{LF})^{2}$ when microfiltering skim milk with 4 -mm round and 4-mm equivalent diameter diamond-shaped channel membranes with uniform transmembrane pressure

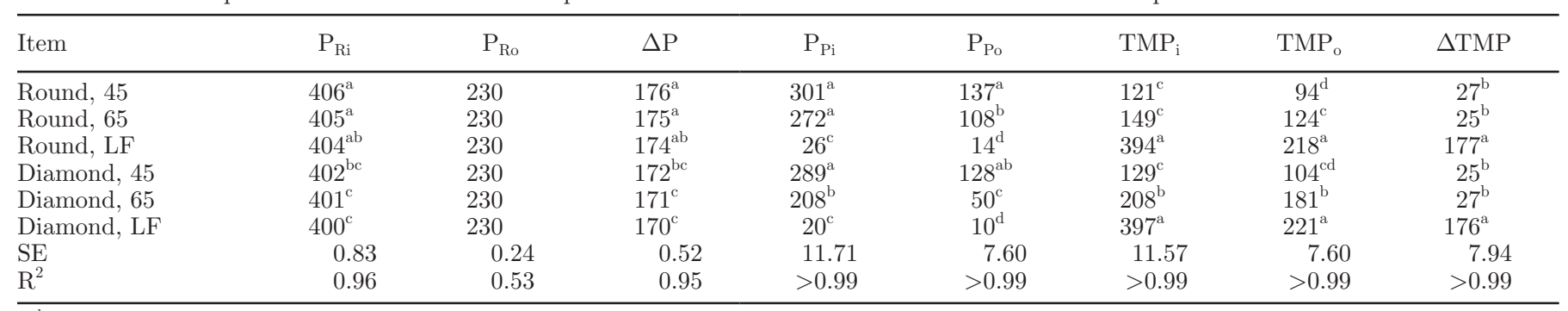

$\overline{\mathrm{a}-\mathrm{d}}$ Means within the same column not followed by the same letter are different $(P<0.05)$.

${ }^{1} \mathrm{P}_{\mathrm{Ri}}=$ inlet retentate pressure; $\mathrm{P}_{\mathrm{Ro}}=$ outlet retentate pressure; $\Delta \mathrm{P}=\mathrm{P}_{\mathrm{Ri}}-\mathrm{P}_{\mathrm{Ro}} ; \mathrm{P}_{\mathrm{Pi}}=$ inlet permeate pressure; $\mathrm{P}_{\mathrm{po}}=$ outlet permeate pressure; $\mathrm{TMP}_{\mathrm{i}}=$ transmembrane pressure at the inlet; $\mathrm{TMP}_{\mathrm{o}}=$ transmembrane pressure at the outlet; $\Delta \mathrm{TMP}=\mathrm{TMP}_{\mathrm{i}}-\mathrm{TMP}_{\mathrm{o}}$.

${ }^{2}$ Mean round and diamond channel membrane $\mathrm{LF}$ were 88 and $71 \mathrm{~kg} \cdot \mathrm{m}^{-2} \cdot \mathrm{h}^{-1}$, respectively.

round channel system at $65 \mathrm{~kg} \cdot \mathrm{m}^{-2} \cdot \mathrm{h}^{-1}$. As the $\mathrm{LF}$ was reached, no differences $(P>0.05)$ in $\mathrm{P}_{\mathrm{Pi}}, \mathrm{P}_{\mathrm{Po}}, \mathrm{TMP}_{\mathrm{i}}$, or $\mathrm{TMP}_{\mathrm{o}}$ were observed between the systems, as both began to foul rapidly. To maintain UTP performance, $\triangle \mathrm{TMP}$ was controlled at $25 \pm 3 \mathrm{kPa}$. Near the $\mathrm{LF}$, $\mathrm{P}_{\mathrm{Po}}$ approached $0 \mathrm{kPa}$. As fouling progressed, the diaphragm valve in the permeate recirculation loop had to be closed more to prevent starving the permeate recirculation pump. Consequently, $\triangle \mathrm{TMP}$ could no longer be controlled and it increased $(P<0.05)$ at the LF for both systems.

Membrane Geometry Comparison Retentate Hydrodynamic Conditions. Mean flow dynamic data for the round and diamond channel systems are shown in Table 6. Average cross-flow velocity was controlled in our study. Whereas minor differences $(P<0.05)$ in cross-flow velocity were noted among treatments and fluxes, these were small $(<0.4 \%)$, inconsistent with respect to the treatments, and were only detected because of the tight control of the system. Because the cross-flow velocity was controlled and the open crosssectional area of the diamond channel membrane was higher than the cross sectional area of the round channel membrane (Figure 1), the retentate recirculation rate required to achieve the same cross-flow velocity was higher $(P<0.05)$ for the diamond channel system. The Re for the round channel system was higher $(P<0.05)$ than that of the diamond channel system. Minor differences in Re can be attributed to variation in retentate viscosity and cross-flow velocity, but the driver of the difference observed between systems was the smaller membrane hydraulic diameter $\left(D_{h}\right)$ of the diamond channel system (Equation 1).

The computational fluid dynamics models of the radial shear rate and radial cross-flow velocity distributions within the round and diamond-shaped retentate flow channels are shown in Figure 6. As expected, shear rates were highest and velocities were lowest near the membrane surface for both channel geometries. The most striking difference between the channel geometries was the localized reduction in shear rate and velocity near the vertices of the diamond-shaped flow channels. Saiyood et al. (2013) used computational fluid dynamics to study the radial cross-flow velocity profiles within star-shaped MF retentate flow channels and determined that cross-flow velocities were lowest in the corners of the channels. Lower shear rates and velocities have been associated with higher fouling and lower LF in cross-flow MF of skim milk (Samuelsson et al., 1997; Gesan-Guiziou et al., 1999). The acute vertex $\left(65.6^{\circ}\right)$ showed a greater reduction in both shear rate and velocity than the obtuse vertex $\left(114.4^{\circ}\right)$. This finding suggests that future design of membranes should strive to reduce small angle vertices in manufacturing to increase the overall shear near the membrane surface. This strategy may be difficult to employ in practice if such designs would weaken the overall structure of the membrane or would decrease the membrane surface area per unit volume of a module.

UTP Comparison Pressures. Mean process gauge pressures for the round channel systems with and without UTP are shown in Table 9. No differences $(P$ $>0.05)$ in $\mathrm{P}_{\mathrm{Ri}}, \mathrm{P}_{\mathrm{Ro}}$, or $\Delta \mathrm{P}$ were observed between systems or among fluxes. When UTP was used at 45 and $65 \mathrm{~kg} \cdot \mathrm{m}^{-2} \cdot \mathrm{h}^{-1}, \mathrm{P}_{\mathrm{Pi}}$ was higher $(P<0.05)$ and $\mathrm{P}_{\mathrm{Po}}$ was lower due to the discharge and suction, respectively, of the permeate recirculation pump. For the same reason, TMP $_{i}$ was lower in the UTP system below the LF. At the LF, both systems began to foul and no longer exhibited these differences $(P>0.05)$. Starling flow occurs when permeate flows back through the membrane and into the retentate. It is detrimental to the process because a portion of the membrane is no longer being used for separation. Starling flow is indicated by negative TMP and was observed at the membrane outlet $\left(\mathrm{TMP}_{\mathrm{o}}\right)$ of the system without UTP below the 

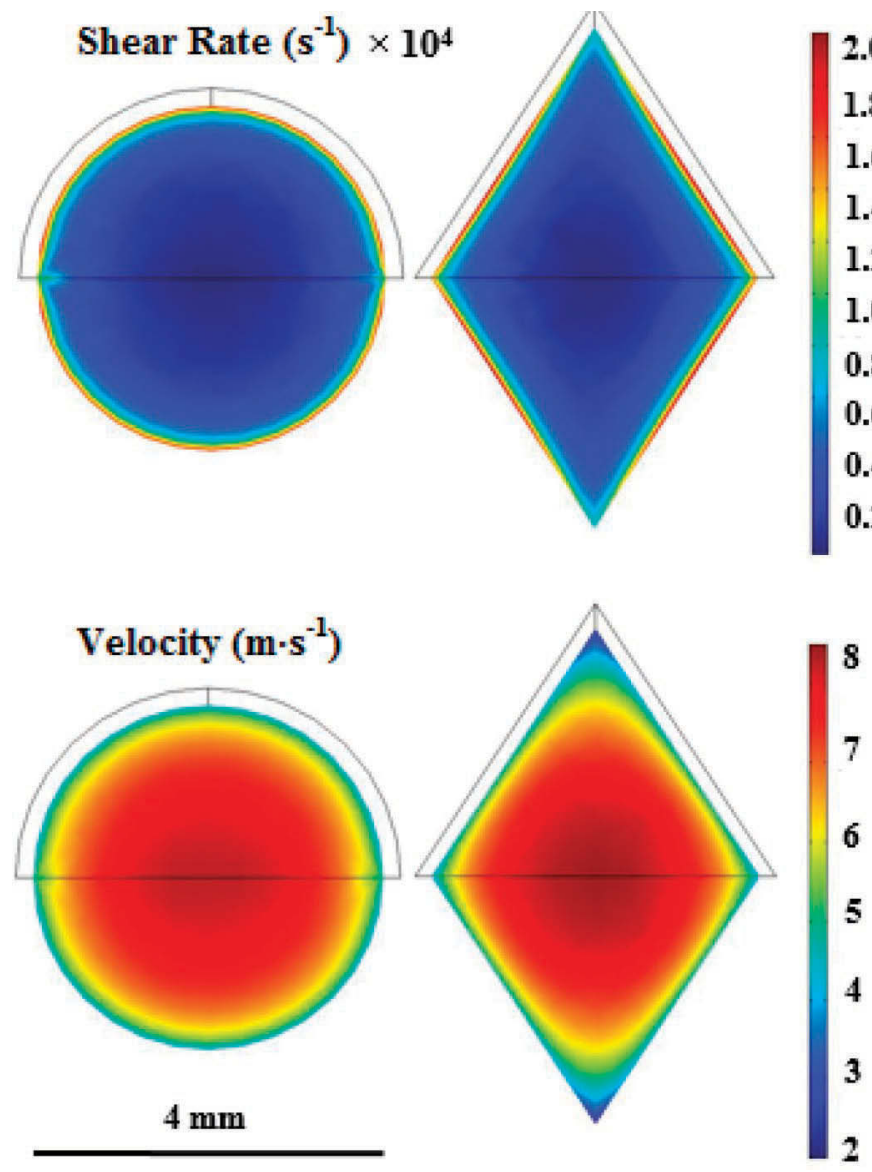

Figure 6. Radial shear rate and cross-flow velocity profiles within the round and diamond-shaped retentate flow channels during microfiltration of skim milk at $50^{\circ} \mathrm{C}$ and an average cross-flow velocity of 7 $\mathrm{m} \cdot \mathrm{s}^{-1}$. Color version available in the online PDF.

LF. Starling flow was reduced by increasing the flux, which reduced backpressure on the permeate side of the membrane. As expected, $\triangle \mathrm{TMP}$ was higher $(P<0.05)$ for the system without UTP than the system with UTP at all fluxes.
UTP Comparison Retentate Hydrodynamic Conditions. Mean flow dynamic data for the round channel systems with and without UTP are shown in Table 7. No differences $(P>0.05)$ in the hydrodynamic conditions were detected among fluxes or between systems. These consistencies can be attributed to the same membrane being used in both systems.

\section{$L F$}

Effect of Membrane Geometry. The LF of the diamond channel system $\left(71 \mathrm{~kg} \cdot \mathrm{m}^{-2} \cdot \mathrm{h}^{-1}\right)$ was lower $(P<0.05)$ than the LF of the round channel system $\left(88 \mathrm{~kg} \cdot \mathrm{m}^{-2} \cdot \mathrm{h}^{-1}\right.$; Figure 7$)$. The difference in LF between the systems (round channel system LF was $24 \%$ higher) was proportional to the difference in Re between the systems (round channel system Re was $25 \%$ higher). Gesan-Guiziou et al. (1999) and Hurt et al. (2015b) determined that the Re is not a good predictor of ceramic MF LF when round channels of different diameters are compared. However, the present study compared channels of different geometries. The critical Re for transition from laminar to turbulent flow in a channel increases with increasing aspect ratio, or the ratio of the length of a channel's cross section to its width (Obot, 1988). Because the aspect ratio for a round channel is 1 (the minimum), this implies that a noncircular channel with the same cross-sectional area as a round channel will transition to turbulent flow at a higher Re. Using $D_{h}$ as the length unit in the Re calculation accounts for differences in critical Re among varying geometries (Obot, 1988) and can be used to reconcile differences in fluid dynamics between flow through circular and noncircular channels. The variation in shear rates and velocities described by the computational fluid dynamics models indicate that the perimeter of the diamond-shaped channel had a higher proportion of low shear near the membrane surface. This finding could be expected to reduce the LF and

Table 9. Mean $(\mathrm{n}=3)$ gauge pressures ${ }^{1}(\mathrm{kPa})$ at 45 and $65 \mathrm{~kg} \cdot \mathrm{m}^{-2} \cdot \mathrm{h}^{-1}$, and limiting fluxes $(\mathrm{LF})^{2}$ when microfiltering skim milk with and without uniform transmembrane pressure (UTP) using 4-mm round channel membranes

\begin{tabular}{|c|c|c|c|c|c|c|c|c|}
\hline Item & $\mathrm{P}_{\mathrm{Ri}}$ & $\mathrm{P}_{\mathrm{Ro}}$ & $\Delta \mathrm{P}$ & $\mathrm{P}_{\mathrm{Pi}}$ & $\mathrm{P}_{\mathrm{Po}}$ & $\mathrm{TMP}_{\mathrm{i}}$ & $\mathrm{TMP}_{\mathrm{o}}$ & $\Delta \mathrm{TMP}$ \\
\hline UTP, 65 & 405 & 230 & 175 & $272^{\mathrm{ab}}$ & $108^{\mathrm{b}}$ & $149^{\mathrm{cd}}$ & $124^{\mathrm{c}}$ & $25^{\mathrm{c}}$ \\
\hline No UTP, 65 & 405 & 230 & 175 & $222^{\mathrm{c}}$ & $232^{\mathrm{a}}$ & $197^{\mathrm{b}}$ & $-3^{\mathrm{d}}$ & $199^{\mathrm{a}}$ \\
\hline No UTP, LF & 405 & 230 & 175 & $55^{\mathrm{d}}$ & $65^{\mathrm{c}}$ & $365^{\mathrm{a}}$ & $166^{\mathrm{b}}$ & $199^{\mathrm{a}}$ \\
\hline SE & 0.75 & 0.24 & 0.83 & 9.70 & 10.44 & 9.73 & 10.58 & 3.77 \\
\hline
\end{tabular}

${ }^{\mathrm{a}-\mathrm{d}}$ Means within the same column not followed by the same letter are different $(P<0.05)$.

${ }^{1} \mathrm{P}_{\mathrm{Ri}}=$ inlet retentate pressure; $\mathrm{P}_{\mathrm{Ro}}=$ outlet retentate pressure; $\Delta \mathrm{P}=\mathrm{P}_{\mathrm{Ri}}-\mathrm{P}_{\mathrm{Ro}} ; \mathrm{P}_{\mathrm{Pi}}=$ inlet permeate pressure; $\mathrm{P}_{\mathrm{po}}=$ outlet permeate pressure; $\mathrm{TMP}_{\mathrm{i}}=$ transmembrane pressure at the inlet; $\mathrm{TMP}_{\mathrm{o}}=$ transmembrane pressure at the outlet; $\Delta \mathrm{TMP}=\mathrm{TMP}_{\mathrm{i}}-\mathrm{TMP}_{\mathrm{o}}$.

${ }^{2}$ Mean UTP and no UTP operation LF were 88 and $84 \mathrm{~kg} \cdot \mathrm{m}^{-2} \cdot \mathrm{h}^{-1}$, respectively. 
can be accounted for by the differences in $D_{h}$. Whether or not $\mathrm{D}_{\mathrm{h}}$ can account for changes in LF when channels of different geometries and different equivalent diameters are compared remains to be confirmed.

Effect of $\boldsymbol{U T P}$. The LF of the round channel system without UTP $\left(84 \mathrm{~kg} \cdot \mathrm{m}^{-2} \cdot \mathrm{h}^{-1}\right)$ was lower $(P<0.05)$ than the LF of the round channel system with UTP (88 $\mathrm{kg} \cdot \mathrm{m}^{-2} \cdot \mathrm{h}^{-1}$; Figure 7$)$. Preliminary work indicated no interaction effect between channel geometry and UTP on the LF (data not shown). It was expected that UTP might have conferred more of an advantage in increasing the system LF because UTP is reported to reduce membrane fouling (Sandblom, 1978). The results of the present study are in line with those of Vadi and Rizvi (2001), who noted that UTP did not improve skim milk MF flux below a $4 \times \mathrm{CF}$ in batch concentration mode using $0.2-\mu \mathrm{m}$ ceramic MF membranes. To realize a marginal $5 \%$ gain in LF by operating the system in UTP mode, processors would also have to absorb the fixed capital and variable energy costs associated with running the additional permeate recirculation pump.

Our study did not determine whether UTP would affect the length of time that the MF process described could be run before fouling would require the system to be cleaned. Based on our experience microfiltering skim milk and milk protein concentrate using ceramic Membralox GP membranes (Hurt et al., 2015a,b; Adams et al., 2015), if the retentate viscosity is kept below a certain value (value is dependent on the cross-flow velocity), cross-flow velocity is maintained, and the flux in a constant flux process is $<85 \%$ of the LF (or TM$\mathrm{P}_{\text {avg }}<150 \mathrm{kPa}$ in a constant TMP process), fouling will remain low and run times near $20 \mathrm{~h}$ can be achieved (E. E. Hurt, unpublished data). If the above guidelines are followed, the use of UTP is not expected to increase run times relative to when UTP is not used. The findings of Vadi and Rizvi (2001) support this hypothesis when CF $<4 \times$. Further work should be done to verify that the findings of our study are valid for the run times that might be used in industry (i.e., $18 \mathrm{~h}$ ).

\section{SP and Permeate Removal}

SP Removal Factor. An SP removal factor was calculated to describe the passage of SP through the 3 systems at 45 and $65 \mathrm{~kg} \cdot \mathrm{m}^{-2} \cdot \mathrm{h}^{-1}$ and the LF (Figure 8). An SP removal factor of 1 indicates that no SP was rejected by the membrane, whereas 0 indicates that all of the SP was rejected. The 0.1- $\mu$ m Membralox GP ceramic membranes have a SP removal factor of 0.87 below the LF (Adams et al., 2015) when microfiltering skim milk. The diamond channel system SP removal factor was 0.86 at $45 \mathrm{~kg} \cdot \mathrm{m}^{-2} \cdot \mathrm{h}^{-1}$ and decreased $(P<$ $0.05)$ to 0.81 as flux was increased to the LF (Figure 8).

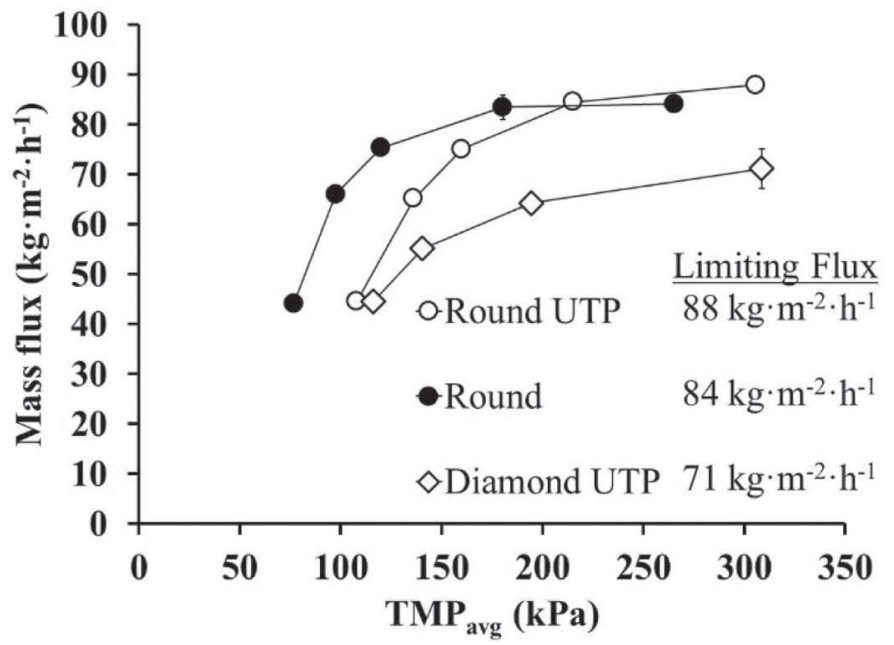

Figure 7. Mean $(\mathrm{n}=3)$ mass flux as a function of average transmembrane pressure $\left(\mathrm{TMP}_{\text {avg }}\right)$ when microfiltering skim milk using 4-mm round channel membranes with and without uniform transmembrane pressure (UTP) and 4-mm equivalent diameter diamond channel membranes with UTP. Temperature $=50^{\circ} \mathrm{C}$; average cross-flow velocity $=7 \mathrm{~m} \cdot \mathrm{s}^{-1}$. Error bars represent $\pm 1 \mathrm{SD}$.

The round channel system SP removal factor was lower $(P<0.05)$ at $45 \mathrm{~kg} \cdot \mathrm{m}^{-2} \cdot \mathrm{h}^{-1}(0.79)$ and decreased $(P<$ $0.05)$ to 0.71 as flux was increased to the LF. The use of UTP did not affect the SP removal factor. Preliminary work indicated no interaction effect between channel geometry and UTP on the SP removal factor (data not shown).

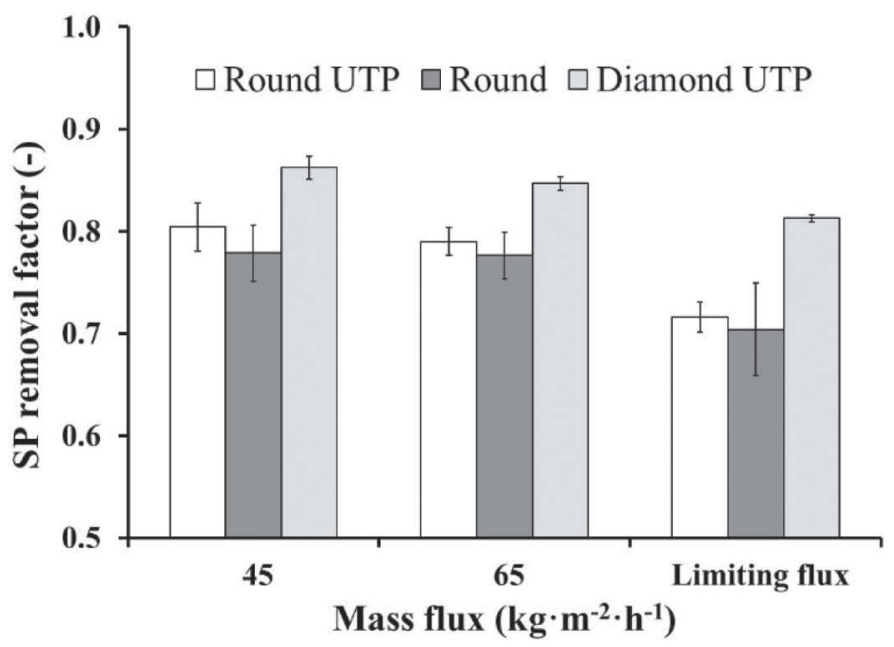

Figure 8. Mean $(\mathrm{n}=3)$ serum protein $(\mathrm{SP})$ removal factors as a function of mass flux when microfiltering skim milk using 4-mm round channel membranes with and without uniform transmembrane pressure (UTP) and 4-mm equivalent diameter diamond channel membranes with UTP. Limiting fluxes for round with UTP, round without UTP, and diamond with UTP were 88,84 , and $71 \mathrm{~kg} \cdot \mathrm{m}^{-2} \cdot \mathrm{h}^{-1}$, respectively. Error bars represent $\pm 1 \mathrm{SD}$. 
The diamond and round channel membranes used in the present study were both specified to have a nominal pore size of $100 \mathrm{~nm}$. The Membralox GP membranes examined by Adams et al. (2015) had a nominal pore size specification of $0.1 \mu \mathrm{m}$. Although the $0.1-\mu \mathrm{m}$ and $100-\mathrm{nm}$ pore sizes should be the same, manufacturing differences may have resulted in the diamond channel membrane pore size being near that of the Membralox GP membranes and the round channel membrane pore size being smaller, based on variation in SP removal. Because a single batch of each membrane type was used in our study, it is not possible to determine whether the SP removal differences were inherent to the geometry manufacturing process or if they were due to random batch-to-batch variation within a given membrane type. Future studies that seek to determine differences in membrane rejection characteristics should examine membranes from several different lots to improve the statistical power in making such claims.

Modular Permeate Removal Rate. Ceramic membranes are typically housed inside stainless steel modules. One way to decrease the fixed costs of ceramic MF systems would be to increase membrane surface area per unit volume of a module so that fewer stainless steel modules are needed to house a given amount of membrane area. The fluxes studied using each system were multiplied by the module surface area so that a modular permeate removal rate (kilograms of permeate per hour) could be calculated. Despite having a lower LF, the diamond channel system achieved a $19 \%$ higher $(P<0.05)$ modular permeate removal rate (Figure 9). This was due to the $47 \%$ increase in module surface area conferred by the diamond channel design. Depending on the size of the system and assuming that SP removal is not decreased by the diamond channel design, the diamond channel system could decrease the fixed costs of a ceramic MF installation relative to a round channel system with retentate flow channels of the same equivalent diameter.

\section{Sensitivity Analysis of Diamond Channel Cross-Sectional Area}

Some of the diamond retentate flow channels had vertices that were slightly more rounded than vertices in other channels. Channels with rounded vertices would have higher cross-sectional areas than channels with sharp vertices of the same height and width. This was not accounted for in our total open channel area (Figure 1) or cross-flow velocity (Table 6) calculations. At a constant retentate recirculation rate (i.e., 676.5 $\mathrm{L} \cdot \mathrm{min}^{-1}$ ), a higher cross-sectional area would result in a lower cross-flow velocity and could be expected to decrease the LF (Hurt et al., 2015b). The diamond chan- nel cross-sectional area calculated in our study $(0.00054$ $\mathrm{m}^{2}$ per element, Figure 8) was based on the assumption that all of the vertices were sharp. A sensitivity analysis was conducted (Table 10) to determine the effect of variation in cross-sectional area on the cross-flow velocity and, consequently, the LF. The analysis assumed LF was linearly proportional to cross-flow velocity (Samuelsson et al., 1997). Increasing the diamond channel cross-sectional area by $12 \%$ (Table 10) yields a cross-sectional area equal to that of a 4-mm round flow channel, and could therefore be considered a reasonable upper limit for the sensitivity analysis. Assuming a $12 \%$ increase in the cross-sectional area for the diamond flow channel membranes used in our study, the actual average cross-flow velocity would have been 6.23 $\mathrm{m} \cdot \mathrm{s}^{-1}$ (Table 10), not $7 \mathrm{~m} \cdot \mathrm{s}^{-1}$. Increasing the average cross-flow velocity from 6.23 to $7 \mathrm{~m} \cdot \mathrm{s}^{-1}$ by increasing the retentate recirculation rate would have increased the diamond channel membrane's LF from 71 to 80 $\mathrm{kg} \cdot \mathrm{m}^{-2} \cdot \mathrm{h}^{-1}$ (Table 10), which would still be lower than the LF observed for the round channel membrane when operated in UTP mode $\left(88 \mathrm{~kg} \cdot \mathrm{m}^{-2} \cdot \mathrm{h}^{-1}\right)$. Assuming the diamond channel $\mathrm{LF}$ was $80 \mathrm{~kg} \cdot \mathrm{m}^{-2} \cdot \mathrm{h}^{-1}$, the modular permeate removal rate at the $\mathrm{LF}$ would have been higher $\left(165 \mathrm{~kg} \cdot \mathrm{h}^{-1}\right.$, Table 10) than the modular permeate removal rate reported $\left(147 \mathrm{~kg} \cdot \mathrm{h}^{-1}\right)$ in Figure 9 . The sensitivity analysis indicated that the round channel LF was at least 10\% higher (assuming rounded vertices and a $12 \%$ increase in cross-sectional area) and at most $24 \%$ higher (assuming sharp vertices and no increase in cross-sectional area) than the diamond channel LF at

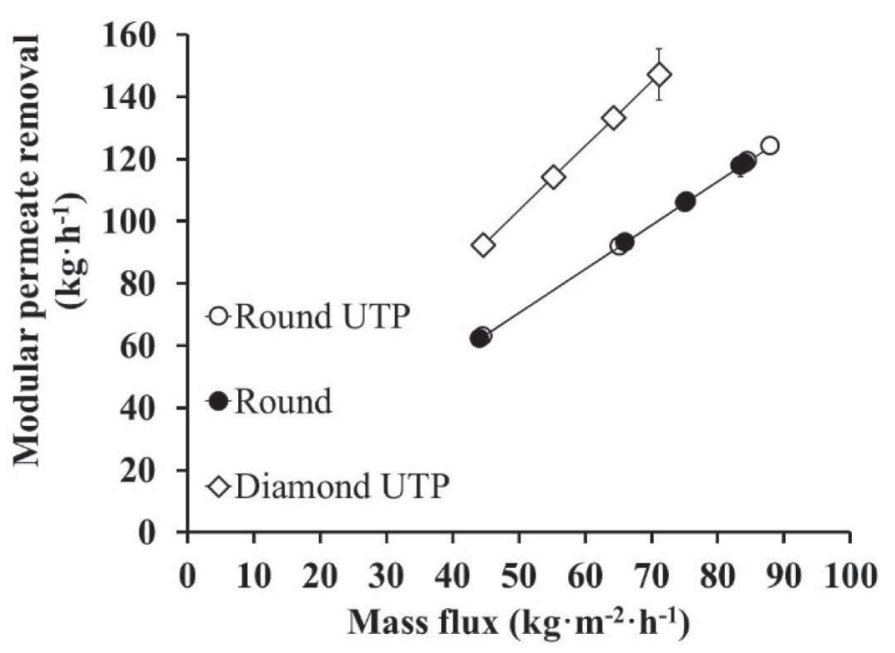

Figure 9. Mean $(\mathrm{n}=3)$ modular permeate removal rates as a function of mass flux when microfiltering skim milk using 4-mm round channel membranes with and without uniform transmembrane pressure (UTP) and 4-mm equivalent diameter diamond channel membranes with UTP. Temperature $=50^{\circ} \mathrm{C}$; average cross-flow velocity $=$ $7 \mathrm{~m} \cdot \mathrm{s}^{-1}$. Error bars represent $\pm 1 \mathrm{SD}$. 
Table 10. Sensitivity analysis of the effect of diamond channel cross-sectional area on hydraulic diameter, average cross-flow velocity, Reynolds number, limiting flux, and modular permeate removal rate

\begin{tabular}{|c|c|c|c|c|}
\hline \multirow[b]{2}{*}{ Parameter } & \multicolumn{4}{|c|}{ Assumed increase in cross-sectional area (\%) } \\
\hline & 0 & 5 & 10 & 12 \\
\hline Module cross-sectional area ${ }^{1}\left(\mathrm{~m}^{2}\right)$ & $1.61 \times 10^{-3}$ & $1.69 \times 10^{-3}$ & $1.77 \times 10^{-3}$ & $1.81 \times 10^{-3}$ \\
\hline Hydraulic diameter $^{2}(\mathrm{~m})$ & $3.2 \times 10^{-3}$ & $3.3 \times 10^{-3}$ & $3.5 \times 10^{-3}$ & $3.6 \times 10^{-3}$ \\
\hline Average cross-flow velocity ${ }^{3}\left(\mathrm{~m} \cdot \mathrm{s}^{-1}\right)$ & 7.00 & 6.67 & $6.37-2$ & 6.23 \\
\hline Reynolds number ${ }^{4}$ & 14,200 & 14,200 & 14,200 & 14,200 \\
\hline
\end{tabular}

${ }^{1}$ Module cross-sectional area $=$ channel cross-sectional area $\times 48$ channels per element $\times 3$ elements per module.

${ }^{2}$ Hydraulic diameter $=4 \times$ channel sectional area/wetted perimeter $(0.014 \mathrm{~m})$.

${ }^{3}$ Velocity $=$ retentate recirculation rate $\left(676.5 \mathrm{~L} \cdot \mathrm{min}^{-1}\right) /$ module cross-sectional area.

${ }^{4}$ Reynold number $=$ retentate density $\left(1,040 \mathrm{~kg} \cdot \mathrm{m}^{-3}\right) \times($ hydraulic diameter $) \times($ average cross-flow velocity $) /$ retentate viscosity $(0.00163 \mathrm{~Pa} \cdot \mathrm{s})$. ${ }^{5}$ Limiting flux at $7 \mathrm{~m} \cdot \mathrm{s}^{-1}=71 \mathrm{~kg} \cdot \mathrm{m}^{-2} \cdot \mathrm{h}^{-1} \times\left(7 \mathrm{~m} \cdot \mathrm{s}^{-1} /\right.$ average cross-flow velocity).

${ }^{6}$ Modular permeate removal rate $=$ limiting flux at $7 \mathrm{~m} \cdot \mathrm{s}^{-1} \times$ module surface area $\left(2.07 \mathrm{~m}^{2}\right)$.

an average cross-flow velocity of $7 \mathrm{~m} \cdot \mathrm{s}^{-1}$. In either case, the modular permeate removal rate would have been higher for the diamond channel system than it was for the round channel system.

\section{CONCLUSIONS}

The effects of ceramic membrane channel geometry (round or diamond-shaped) and UTP on LF and SP removal during skim milk MF at a temperature of $50^{\circ} \mathrm{C}$, a retentate protein concentration of $8.5 \%$, and an average cross-flow velocity of $7 \mathrm{~m} \cdot \mathrm{s}^{-1}$ were determined. Using UTP with round flow channel MF membranes increased the LF by $5 \%$ when compared with not using UTP and SP removal was not affected by the use of UTP. Using membranes with round channels instead of diamond-shaped channels in UTP mode increased the LF by $24 \%$. This increase was associated with a $25 \%$ increase in Re and can be explained by lower shear at the vertices of the diamond-shaped channel's surface. The SP removal factor of the diamond channel system was higher than the SP removal factor of the round channel system below the LF. However, the diamond channel system passed more casein into the MF permeate than the round channel system. Because only one batch of each membrane was tested in our study, it was not possible to determine if the differences in protein rejection between channel geometries were due to the membrane design or random manufacturing variation. Despite the lower LF of the diamond channel system, the $47 \%$ increase in membrane module surface area of the diamond channel system produced a modular permeate removal rate that was at least 19\% higher than the round channel system. Consequently, using diamond channel membranes instead of round chan- nel membranes could reduce some of the costs associated with ceramic MF of skim milk if fewer membrane modules could be used to attain a given amount of membrane area.

\section{ACKNOWLEDGMENTS}

The authors thank the New York State Milk Promotion Board (Albany, NY) and Northeast Dairy Foods Research Center (Ithaca, NY) for partial funding of this research. The technical assistance of Michelle Bilotta, Sara Bova, and Chassidy Coon from the Department of Food Science at Cornell University was greatly appreciated. The authors also thank Alexander Warning from the Department of Biological and Environmental Engineering at Cornell University for his help in developing the COMSOL models.

\section{REFERENCES}

Adams, M. C., and D. M. Barbano. 2013. Serum protein removal from skim milk with a 3 -stage, $3 \times$ ceramic Isoflux membrane process at $50^{\circ}$ C. J. Dairy Sci. 96:2020-2034.

Adams, M. C., E. E. Hurt, and D. M. Barbano. 2015. Impact of soluble calcium and lactose on limiting flux and serum protein removal during skim milk microfiltration. J. Dairy Sci. 98:7483-7497.

AOAC International. 2000. Official Methods of Analysis. 17th ed. AOAC International, Gaithersburg, MD.

Bacchin, P., P. Aimar, and R. W. Field. 2006. Critical and sustainable fluxes: Theory, experiments, and applications. J. Membr. Sci. 281:42-69.

Belfort, G., R. H. Davis, and A. L. Zydney. 1994. The behavior of suspensions and macromolecular solutions in crossflow microfiltration. J. Membr. Sci. 96:1-58.

Cheryan, M. 1998. Ultrafiltration and microfiltration handbook. Page 339 in Costs and Processing Economics. Technomic Publishing Company Inc., Lancaster, PA.

Chiu, T. Y., M. V. Lara Dominguez, and A. E. James. 2005. Noncircular ceramic membranes for use in wastewater treatment. Environ. Prot. Eng. 31:53-60. 
COMSOL. 2013. Which turbulence model should I choose for my CFD application? Accessed Mar. 13, 2015. http://www.comsol.com/ blogs/which-turbulence-model-should-choose-cfd-application/.

Elwell, M. W., and D. M. Barbano. 2006. Use of microfiltration to improve fluid milk quality. J. Dairy Sci. 89:E20-E30.

Gesan-Guiziou, G., G. Daufin, E. Boyaval, and O. Le Berre. 1999. Wall shear stress: Effective parameter for the characterization of the cross-flow transport in turbulent regime during skimmed milk microfiltration. Lait 79:347-354.

Hurt, E., and D. M. Barbano. 2010. Processing factors that influence casein and serum protein separation by microfiltration. J. Dairy Sci. 93:4928-4941.

Hurt, E., J. Zulewska, M. Newbold, and D. M. Barbano. 2010. Micellar casein concentrate production with a $3 \times, 3$-stage uniform transmembrane pressure ceramic membrane process at $50^{\circ} \mathrm{C}$. J. Dairy Sci. 93:5588-5600.

Hurt, E. E., M. C. Adams, and D. M. Barbano. 2015a. Microfiltration: Effect of retentate protein concentration on limiting flux and serum protein removal with 4-mm-channel ceramic microfiltration membranes. J. Dairy Sci. 98:2234-2244.

Hurt, E.E., M.C. Adams, and D.M. Barbano. 2015b. Microfiltration: Effect of channel diameter on limiting flux and serum protein removal. J. Dairy Sci. 98:3599-3613.

Kaylegian, K. E., G. E. Houghton, J. M. Lynch, J. R. Fleming, and D. M. Barbano. 2006. Calibration of infrared milk analyzers: Modified milk versus producer milk. J. Dairy Sci. 89:2817-2832.

Obot, N. T. 1988. Determination of incompressible flow friction in smooth circular and noncircular passages: A generalized approach including validation of the nearly century old hydraulic diameter concept. J. Fluids Eng. 110:431-440.

Pafylias, I., M. Cheryan, M. A. Mehaia, and N. Saglam. 1996. Microfiltration of milk with ceramic membranes. Food Res. Int. $29: 141-146$.

Saiyood, K., E. Bumrungthaichaichan, S. Wattananusorn, and W. Chandra-ambhorn. 2013. CFD modeling of microfiltration membrane with seven star-shaped channels. Ladkrabang Eng. J. 30:4348.

Samuelsson, G., I. H. Huisman, G. Tragardh, and M. Paulsson. 1997. Predicting limiting flux of skim milk in crossflow microfiltration. J. Membr. Sci. 129:277-281.

Sandblom, R. M., inventor. 1978. Filtering process. Alfa-Laval AB, assignee. US Pat. No. 4,105,547.

Vadi, P. K., and S. S. H. Rizvi. 2001. Experimental evaluation of a uniform transmembrane pressure crossflow microfiltration unit for the concentration of micellar casein from skim milk. J. Membr. Sci. 189:69-82.

Verdi, R. J., D. M. Barbano, M. E. Dellavalle, and G. F. Senyk. 1987. Variability in true protein, casein, nonprotein nitrogen, and proteolysis in high and low somatic cell milks. J. Dairy Sci. 70:230-242.

Wojciechowski, K. L., and D.M. Barbano. 2015. Modification of the Kjeldahl noncasein nitrogen to include bovine milk concentrates and milks from other species. J. Dairy Sci. 98:7510-7526.

Zulewska, J., M. Newbold, and D. M. Barbano. 2009. Efficiency of serum protein removal from skim milk with ceramic and polymeric membranes at $50^{\circ}$ C. J. Dairy Sci. 92:1361-1377. 